\title{
Responsabilidade Civil e Consentimento do Lesado: Um Contributo da Experiência Portuguesa à Ordem Jurídica Brasileira
}

Felipe Teixeira Neto'

I Introdução. 2 Consentimento do Lesado e Exclusão da llícitude. 2.10 Consentimento do Lesado como Causa Justificadora do Fato Danoso. 2.2 Consentimento do Lesado e Figuras Afins: Diferenciaçâo Necessária. 30 Regime Geral de Justificação pelo Consentimento 4 Os Limites da Justificação pelo Consentimento. 5 Formas Altemativas ao Concentimento Expresso, 5.10 Consentimento Tácito e a Importancia da Assunção dos Riscos. 5.2 Presunçāo de Consentimento: a Atuação em Interesse Alheio. 6 Conclusão. Referências.

Resumo: O presente artigo propôe-se a analisar a relevância do consentimento do lesado em tema de responsabilidade civil, em especial seu papel na exclusāo da ilicitude da conduta. Para tanto, buscando substrato na experiência portuguesa, em que o instituto encontra-se já bastante desenyolvido, apresentar-se-á a dogmática da causa de justificação em exame no seu regime geral e nas modalidades a ele altemativas, objetivando traçar uma regulamentaçắo adequada ao ordenamento jurídico brasileiro.

Palavras-chave: Consentimento do Lesado. Direito Civil. Ilicitude: Justificação. Responsabilidade Civil.

Abstract: This article proposes to examine the relevance of the victim's consent on the Tort Law, in particular its role in the rejection of the unlawful conduct. For both, seeking substrate in Portuguese experience, where the institute is already well developed, it will present the dogmatic of this cause of justification in a general and alternative modalities, to propose an appropriate regulation to Brazilian law.

Keywords: Civil Law: Consent of the Victim. Justification. Tort Law. Unlawful.

\section{Introdução}

A responsabilidade civil vem sendo amplamente reconhecida como uma das temáticas que, a par dos diversos

\footnotetext{
Mestrando em Direito Civil pela Universidade de Lisboa, Portugal, Especialista em Direito Ambiental pela Universidade de Passo Fundo, RS, Professor de Direito Civil nos cursos de Graduacáo e Pós-Graduacâo da Universidade Regional Integrada do Alto Uruguai e das Missoes (Erechim, RS), Promotor de Justiça no Estado do Rio Grande do Sul.
} 
reveses sofridos ao longo da história do direito, nomeadamente no que toca às funções que lhe foram atribuídas, despertou e continua despertando intensa atenção dos juristas. Isso porque o incremento da complexidade social tem demandado o alargamento cada vez maior dos seus campos de atuação, sendo a sua aplicação chamada a solver impasses de ordens variadas, fruto de uma ampliação das demandas sociais.

Daí porque, a fim de que bem desenvolva o seu mister, necessita ter seus pressupostos bastante bem delineados. Ou seja, é necessário que seus aplicadores tenham adequada compreensão dos elementos que serão imprescindíveis à imposição do dever de indenizar decorrente do juízo de imputação civil Neste campo é que conceitos como dano, ilicitude, culpa e risco devem ser assimilados, sob pena de ineficaz manejo da responsabilidade civil e inadequada resposta às demandas que lhe são postas.

Adquire importância, de igual modo, a demarcação das hipóteses em que, mesmo à vista de situaçôes de aparente surgimento do dever de indenizar, concorrerão causas que, por comprometerem a higidez de um dos seus pressupostos; implicarăo a não-formaçắo do juízo de imputação de responsabilidade.

Neste contexto é que se insere a presente investigação, a qual se propõe a analisar a relevância do consentimento do lesado em tema de responsabilidade civil. Em outras palavras, verificar os reflexos que o consentimento do titular dos interesses protegidos pela ordem jurídica pode ter na estatuiçấo do dever de indenizar, nomeadamente, no que toca aos seus contornos e limites.

Para tanto, o objeto da pesquisa centrar-se-á em um exame de direito comparado entre o tratamento que a matéria recebe nas ordens jurídicas portuguesa e brasileira, as quais, a par da inegável comunhão de princípios e regras que a história conjunta de ambos os países permitiu, apresentam, quanto ao tema, diversidades um tanto quanto relevantes, dada a ausência completa de regulação nesta, em 
contraponto ao notoriamente reconhecido exemplar regulamento existente naquela.

Daí porque, a partir da experiência portuguesa no trato da matéria, objetivar-se-á identificar a dogmática do instituto em exame, nos seus regimes geral e especial, propondo, a seguir, a verificação da sua compatibilidade com a ordem jurídica brasileira.

Do ponto de vista legislativo, será realizado um contraponto entre as regras jurídicas vigentes em Portugal e no Brasil, mesmo que, algumas delas, de cunho geral, verificando, inclusive, a necessidade de reforma neste aspecto. Sem prejuízo, as referências à doutrina procurarão ser as mais fartas possiveis, dentro das limitaçóes que um estudo deste porte encerra. Procurar-se-á, de igual modo, quando oportuno, lançar mão de recurso à doutrina penal sobre o tema, até mesmo em razäo da sua maior fartura e sistematização, empregando-se esforços na transposição dos seus resultados a uma utilização no âmbito do direito civil.

\section{Consentimento do Lesado e Exclusão da Ilicitude}

2.1 O consentimento do lesado como causa justificadora do fato danoso

A figura do consentimento do lesado vem associada ao brocado latino in volenti non fit iniuria. Segundo este, a invasão da esfera jurídica alheia pelo autor da ação supostamente danosa, desde que por ele consentida, seria lícita, afastando, pressuposto indispensável do dever de indenizar, qual seja, a ilicitude.

Pela índole do direito civil, as pessoas são livres para abdicar da tutela que a lei lhes confere, desde que os interesses envolvidos revistam-se de disponibilidade, sendo, pois, o consentimento do lesado em relação à violação de interesses que lhe é impingida pelo agir de outrem uma "manifestaçẫo de liberdade subjacente à tutela privada" (CORDEIRO, $2007 \mathrm{~b}, \mathrm{p}$. 455). Daí a justificativa para a inclusāo da figura em 
apreço no rol das excludentes de ilicitude relacionadas ao exercício e à tutela dos direitos, como o faz o Código Civil português.

Em desdobramento a esta indução feita acerca do consentimento do lesado, ${ }^{2}$ várias foram as construções buscando justificar o fundamento para que tal aquiescência ${ }^{3}$ bastasse à exclusão da ilicitude. ${ }^{4}$

A doutrina costuma identificar a sua gênese, no pensamento moderno, na denominada Teoria do Negócio Jurídico, de Ernst Zitelmann, a qual "concebía el consentimiento como um negocio jurídico privado, mediante el cual se otorgaba um derecho de intervención revocable" (ROXIN, 1997, p. 533). Dita teoria foi objeto de intensa crítica, pois, segundo seus opositores, o consentimento não cria ao lesante a faculdade de ingerir na esfera jurídica do lesado, năo havendo do que se falar no nascimento de direito subjetivo para este (MEZGER, 1946, p. 398).

\footnotetext{
${ }^{2}$ Existe divergencia na doutrina acerca da melhor expressão para denominar o consentimento em estudo. Há quem sustente que a expressão "consentimento do ofendido" - e, pelas mesmas razōes, a aqui empregada "consentimento do lesado" - não seria adequada, já que o sujeito passivo da ação năo é ofendido e tampouco lesado, pois contra ele năo existe ofensa ou lesão propriamente distas. Em razão disso, sustenta-se a preferibilidade da expressão "consentimento do interessado" ou, em traduçầo da expressâo taliana consenso dell avente diritto, "consentimento do titular do direito" (MAGALHĀES, 1968, pp. 107 109). O uso alargado da expressáo que dá título à presente investigaçao, contudo, sem se desconsiderar as ponderaçôes teóricas a respeito, autoriza o seu emprego, até como meio de uniformidade da temática, já que corriqueiramente empregada no direito positivo de vários países.

${ }^{3} \mathrm{Na}$ verdade, conforme Maurício Macedo dos Santos e Viviane Amaral Sêga (2008, p. 4), a expressäo "aquiescência" exprime manifestação que pode ser externaíizada por meio de consentimento ou por meio de acordo, sendo gênero do qual os referidos são espécies. Neste estudo, porém, considerando que a doutrina que trata do tema en exame assim também o faz, bem como tendo em vista que o acordo não é óbjeto da investigação, será empregado o termo "aquiescência" como referência apenas ao consentimento do lesado.

${ }^{4}$ Para uma evoluçâo do pensamento jurídico acerca da relevância do consentimento do lesado em matéria de exclusão da ilicitude, desde a sua gênese tomana até a Escola Sociológica do Direito, passando pelas Escolas do Direito Natural e Histórica do Direito e pelo pensamento de Hegel, oportuno conferi-se o magistério de HamsHeinrich Jescheck e Thomas Weigend (2002, pp. 404 e ss).
} 
Na seqüência, já com um viés mais ligado à doutrina criminal, mas com fundamento igualmente útil ao direito civil, merece destaque a Teoria do Desinteresse do Estado, defendida, na Alemanha, por Edmundo Mezger e, na Itália, por Vicenzo Manzini e Giuseppe Maggiore. Segundo a referida, o que justifica a possibilidade de o consentimento do lesado excluir a ilicitude da conduta é o abandono consciente do interesse por parte de quem legitimamente tem a faculdade de dispor em relação ao bem jurídico (MEZGER, 1946, p. 397).

De seguida, como um desdobramento da anterior, guardando relação mais com a idéia de disponibilidade do que de interesse, merece registro a Teoria da Ação Jurídica, defendida por Berling, mas também presente na obra de Mezger (1946, p. 398), segundo a qual o consentimento representaria uma renúncia do titular à proteção que lhe é conferida pelo ordenamento jurídico, do que decorre a justificaçâo da conduta que dera causa à lesão (SANTOS; SEGA, 2008, p. 3).

Esta teoria parece ser a justificativa, hoje, mais aceita pela doutrina civilista para a excludente em estudo, ${ }^{5}$ como se pode verificar a partir da exposição dos autores contemporâneos, até mesmo em decorrência da sua associação a direitos disponíveis, como adiante se verá, sem prejuízo de desdobramentos diversos que the possam ser dados.

Daí que, segundo Adriano de Cupis (1979, p. 270), não haveria justificativa para a manutenção da tutela conferida ao particular pelo direito nos casos em que este consentisse com a lesão, porque dito consentimento torná-lo-ia partícipe da causa do dano. Ou seja, faria com que a sua vontade, somada a do autor do fato danoso, fosse a responsável pela lesão nas palavras do autor, o lesado apropriar-se-ia da causa do dano -, concorrendo, desta feita, para o resultado, o que, por isso, propiciaria a exclusão da ilicitude. ${ }^{6}$

\footnotetext{
"E a doutrina predominantemente aceita, da mesma forma, em matéria penal (JESCHECK; WEIGEND, 2002, p. 404).

* Na doutrina jurídica de língua portuguesa esta posição é sustentada por Adriano Vaz Serra (1959, p. 104).
} 
Fernando Pessoa Jorge (1995, p. 270) critica a proposiçăo antes referida. Para tanto, menciona que a aquiescência do ofendido não lhe faz partícipe da causa do dano, não obstante concorde que ela seja a causa da ausência de justificativa para a tutela pelo direito. Segundo o autor, o fundamento da justificação "está, sim, na eliminação do condicionalismo que, não havendo tal consentimento, tornaria o dano injusto. A vontade do lesado năo é causa do prejuízo, e isso explica que possa haver obrigação de indenizar, nāo obstante a licitude da ofensa consentida".

No mesmo norte, José Carlos Brandão Proença (1997, p. 611 ), para quem "ao consentir na lesão danosa é o próprio lesado que valora juridicamente a sua vontade dispositiva, dotando-a de um sentido legitimador da lesão efectiva de interesses seus", o que resta, em razão disso, por excluir a ilicitude do fato causador do dano, já que ausente a contrariedade ao direito necessária ao juízo de imputação civil.

Com efeito, é de concluir que, no âmbito da responsabilidade civil, a razão está com os dois últimos autores citados, na medida em que, não obstante a renúncia [rectius, disponibilidade] da proteção concedida pelo direito seja o fundamento convergente para a excludente em apreço, não há como se dizer que o consentimento do ofendido foi, realmente, causa do dano, foi condição imprescindível, ao menos faticamente, à sua realização, sendo requisito que guarda relação com o pressuposto da ilicitude e não da causalidade. O consentimento. é, isso sim, além de representar disposição da proteção concedida, um ato legitimador da ingerência na esfera jurídica do seu titular, o que lhe exclui a pecha de contrariedade ao direito.

Tal debate em torno do fundamento jurídico da hipótese de exclusão em apreço, contudo, sem prejuízo da impropriedade semântica que a imputação da causa ao próprio lesado possa trazer, confundindo-a com pressuposto diverso da responsabilidade civil (DE CUPIS, 1979, p. 270), nāo parece ser de alcance vital à aplicação prática do instituto, não obs-tante contribua para a sua confusão com outros de efei- 
to prático semelhante. Isso porque é consenso na doutrina que o que legitima a conduta lesiva e, destá feita, excluí a sua ilicitude indiciária, é a renúncia do próprio interessado à proteção jurídica que the fora concedida pelo ordenamento juridico. ${ }^{7}$

Em outras palavras,

[...] o direito protege a esfera jurídica dos particulares através da ilicitude, que resulta da interferência em bens ou interesses alheios. Todavia, se há autorização do respectivo titular, essa lesão torna-se lícita. Desaparece, portanto, o motivo da indenizaçấo ou reparaçấo em que se traduz a responsabilidade civil (COSTA, 1991, p. 501).

É premissa para tanto compreender que a responsabilidade civil, de um modo geral, é disposta à proteção de bens integrantes do patrimônio jurídico do titular. Por isso, tratando-se de bens, de regra, disponíveis, é permitido ao destinatário possa dela abrir mäo, daí decorrendo o caráter de exclusão da ilicitude que se atribuirá ao consentimento do lesado.

Se a ilicitude está constituída na contrariedade ao direito que decorre da violação de normas de comportamento predispostas o assentimento do titular dos interesses por ela protegidos, basta eliminar o caráter devido do comportamento (JORGE, 1995, p. 161). Daí que quando a ação danosa for previamente consentida, estará ausente a antijuridicidade que decorreria da violaçấo desse dever de abstenção diante da esfera juridicamente protegida do lesado.

\footnotetext{
${ }^{2}$ Neste sentido, António Mezeres Cordeiro (2007b, p. 457), segundo guem "o consentimento do lesado encontra a sua justificação básica na liberdade pressuposta pelos direitcs subjectivos". Er de igual modo, Adriano De Cupis (1979, p. 270), após fazer referência à apropriação da causa pelo lesado, posição antes criticada refere que $\sigma$ consentimento do ofendido implica renúncia à proteçẫo jurídica do interesse em causa. Com igual ponto de vista, dentre outros, Jorge Ribeiro de Fana (1991, p. 449) e Luis Manuel Teles de Menezes Leităo $(2000, \mathrm{p} .312)$. Dai porque ser possivel afirmar que, en verdade, o pensamento civilista contemporâneo, mesmo que com desdobramentos diversos, converge para o acolhimento da antes referida Teoria da Açâo Juridica.
} 
Desta feita, objetivando delinear a figura em estudo, acompanhando a lição de João de Matos Antunes Varela (1998, p. 552), poder-se-ia dizer que o consentimento do lesado "consiste na aquiescência do titular do direito à prática do acto que, sem ela, constituiria uma violação desse direito ou uma ofensa da noma tuteladora do respectivo interesse $"$. Representa, pois, o consentimento, a disposição da proteção jurídica estatal a interesse privado, excluindo, desta feita, a contrariedade ao direito que decorreria da lesão a este causada.

2.2 Consentimento do lesado e figuras afins: diferenciação necessária

Urge, contudo, a fim de bem delimitar a pesquisa, diferenciar a figura do consentimento do ofendido de outras que lhe sejam próximas - ou, melhor, com as quais, não raro, seja confundida $^{8}$-, dando abrangềncia precisa à investigação.

A primeira delas é a cláusula de exclusão de responsabilidade, segundo a qual, no âmbito de uma relação obrigacional preexistente, ${ }^{9}$ uma das partes, desde logo, pode estabelecer a inexistência do dever de indenizar de outra

\footnotetext{
${ }^{8}$ Segundo Fernando Pessoa Jorge (1998, p. 274), a confusăo entre o consentimento do lesado e diversas outras figuras de relevância juńdica deve-se ao fato de, nào obstarte, em muitos dos casos, dizerem respeilo a pressupostos distintos da responsabilidade civil e, até, en outros, guardarem relaçăo apenas com a indenização, em última análise, lerminarem, todas elas, por acarretar o mesmo "resultado prálico da irresponsabilidade do agente".

" Nấo há consenso na doutrina acerca da aplicabilidade da exclisẫo da ilicitude pelo consentimento do lesado aos casos de responsabilidade obrigacional Enquanto António Menezes Cordeiro (2007b, p. 456) sustenta que o instituto aplica-se somente aos casos de responsabilidade aquiliana, há quem defenda, mesmo que em hipóteses mais restritas, o seu cabimento em casos de responsabildade contratual (PRATA, 1985, p. 153). A primeira posiça parece ser a mais adequada, sendo notóna a vinculação da excludente em apreço às hipóteses de responsabilidade aquiliana, porquanto relacionada à disposiçâo da proteçâo estatal conferida a determinados bens jurídicos do interessado, que podem ser objeto de lesáo por terceiro não vinculado por relação obrigacional preexistente. A adocăo deste pensamento ja bastaria para bem diferenciar as figuras, sendo o consentimento do lesado restrito ấs hipóteses de responsabilidade aquiliana e a cláusula de irresponsabilidade aos casos de responsabilidade negecial Diante, contudo, da existência de diferenças outras e da ausência de consenso acerca da restrição da incidência da causa de justificaçăo em pauta aos casos de responsabilidade contratual, realizar-se-tí o seu exame mais acurado.
} 
em razão de danos eventualmente ocorridos. Ou, como prefere José Carlos Brandão Proença (1997, p. 611), por meio de cláusula preestabelecida, promove-se "a renúncia antecipada do lesado a fazer valer o seu direito secundário de indemnização".

Conforme aponta Adriano Vaz Serra (1959, p. 104), a doutrina francesa, quando aborda o consentimento do lesado, incorre nesta confusão entre os institutos, pois pốe o problema do assentímento do ofendido como se tratando de cláusula de irresponsabilidade, "de modo que o consentimento da vítima teria o efeito de afastar as presunçóes de culpa do autor do dano, mas teria a responsabilidade deste no caso de culpa provada".

O tratamento das figuras em debate por meio de fundamento idêntico, todavia, não parece ser a soluçâo mais acertada. Isso porque ambas, não obstante acarretem a mesma consequêencia econốmica, qual seja, a ausência da obrigação de reparar o dano, apresentam pressupostos muito distintos.

Tanto que, consoante adverte Adriano de Cupis (1979, p. 270), a diferença entre o consentimento do lesado e a cláusula de irresponsabilidade é profunda, pois enquanto esta exclui apenas a consequência junídica do dano, tendo, por conseguinte, mera eficácia dispositiva do direito ao ressarcimento, aquele implica eficácia dispositiva de direito primánio (diritto primario), sendo consequêencia reflexa a disposiçăo do direito ao ressarcimento.

Pelo que se pode perceber, os efeitos jurídicos dos institutos em apreço são, efetivamente, deveras distintos, não obstante, do ponto de vista fático, a consequência seja a mesma. Enquanto no consentimento do lesado exclui-se a ilicitude do fato em decorrência da disposiçâo da própria proteção conferida pelo direito àquele interesse juridicamente protegido, sendo a ausência de dever de indenizar uma decorrência reflexa disso, na cláusula de exclusão da responsabilidade o fato causador do dano não deixa de ser ilícito, sendo que apenas o lesado não pode postular a devida reparação. 
Até porque os desdobramentos possíveis, a partir da ausência do dever de indenizar, serão diversos, em decorrência da ausência, em apenas uma das duas figuras, da ilicitude (no caso, no consentimento do lesado). Isto é, como na cláusula de exclusão de responsabilidade a conduta danosa nẫo deixa de ser ilícita, sendo tâo-só afastada, para o ordenamento jurídico, a relevância do dano (SERRA, 1959. p. 104), năo obstante o lesado faleça de pretensáo indenizatória, tal poderá, v.g. com base no mesmo inadimplemento contratual causador da lesão, postular a resoluçâo da avença ou a sua execução específica (MONTEIRO, 1985 , p 132).

Ainda, no direito português, ${ }^{10}$ por força da regra do artigo 809 do Código de 1966," a qual inquina de nulidade as cláusulas contratuais que impliquem renúncia antecipada aos direitos que porventura venham a nascer em decorrência da mora ou do incumprimento, verifica-se uma significativa restriçẩo ao ấmbito de disponibilidade dos efeitos da responsabilidade civil negocial: ${ }^{12}$ Tal não ocorre em matéria de consentimento do lesado, no qual basta que sejam observados os requisitos estatuídos para a sua ocorrência, que adiante serấo tratados, fazendo com que, em relaçäo a dita hipóte-

\footnotetext{
" Aqui se deixa de fazer registros acerca do direito brasileiro, porquanto inexistem disposiçöes restritivas da incidencia das cláusulas de responsabilidade tal qual ocorne no direíto luso, salvo, por evidente, nos casos de violaçăo de normas de ordem pública, nomeadamente em materia de direito do consumidor Neste sentido dispó o artigo 25 caput, da Lei n $8.078 / 90$ - Código de Protecäo e Defesa do Consumidor segundo o qual [é] vedada a estipulacão contratual de cláusula que impossibilite, exonere ou atenue a obrigaça de indenizar prevista nesta e nas Secoes anteriores, o qual deve ser interpretado em conjunto com o arigo 51 , neiso I do mesmo Código, que declara nula de pleno direlto as cláusulas que impossibilitem, exonerem ou atenuem a responsabilidade do fornecedor por vícios de qualquer natureza dos produtos e serviços ou impliquem em renuncia ou disposicäo de direitos". Tal induz no sentido da impossibilidade de renúcia prévia a indenizaça por parte do consumidor.

"Segundo o dispositivo mencionado, "é nula a clấusula pela qual o credor renuncia antecipadamente a qualquer dos direitos que he sâo facultados nas divisós anteriores nos casos de náo cumprimento ou mora do devedor, salvo o disposto no n. 2 do. artigo $800^{\circ}$.

"Com mesmo escopo, limitando a incidencia das clausulas de irresponsabilidade, o artigo 1229 do Código Civil italiano, segundo o qual será considerada nula a avença que exclua ou limite responsabilidade em caso de eventual dano decorrente de dolo; culpa grave ou violação de noma de ordem pública.
} 
se de justificação, a margem de disposição do titular da proteçâo jurídica apresente-se mais ampla quando comparada com a cláusula de exclusão de responsabilidade (JORGE, 1995, p. 276; SERRA. 1959, p. 104).

$\mathrm{Na}$ seqüencia, poder-se-ia falar de outras duas figuras de resultado bastante próximo àquele decorrente do consentimento do lesado e da cláusula de irresponsabilidade, quais sejam, a remissão e a renúncia ao direito de indenização. Nestas, da mesma forma, a diferença diz respeito à existência do direito primário, a qual só resta afastada pela exclusão da ilicitude que se verifica na primeira figura, consoante já mencionado. ${ }^{13}$ Assim, pode-se afirmar que enquanto na remissão e na renúncia ao direito à indenização a obrigação de reparar o dano nasce e se extingue em decorrência de um ato de disposição do seu titular - ato que, aqui, contrariamente ao que sucede com a cláusula de exclusão de responsabilidade, não necessita ser prévio ao dano -, na aquiescència do ofendido, ela sequer chega a existir, uma vez que ausente o pressuposto da ilicitude (JORGE, 1995, p. 274).

Mais uma figura que merece especial atenção quando se fala em consentimento do lesado, pela freqüente confusão entre ambas, é a culpa exclusiva ou concorrente da vítima. Até porque, como se pôde ver antes, uma das justificativas para a exclusão da ilịcitude em decorrếncia da anuência do ofendido em relação à conduta danosa fora, justamente, a

\footnotetext{
13. No plano criminal, corho exemplo da confusão entre os institutos da renúncia e do consentimento justificante, registre-se que o Código Penal brasileiro de $1890, \mathrm{~m}$ seu artigo 26 , alínea " $c$ ", estabelecia que "[n]ẫo dirimem nem excluem a intençäo criminosa: [...] c) o consentimento do ofendido, menos nos casos em que a lei só a ele permite a ação criminal*. Aqui, em verdade, tratava-se de consagraçăo legislativa do consentimento como renúncia ao direito de queixa e näo como excludente de ilicitude. Ou seja, na hipôtese entäo prevista na legislaçâo brasileira criminal, restava afastada apenas persecução penal, em paralelo com o que aconteceria na responsabilidade civil se afastada apenas a indenizaça, ao passo em que caso o consentimento fosse real causa de justificação, restaria excluído o próprio crime - ou, mais uma vez em paralelo com o juízo de imputação cível, o prốprío ato ilícito: 0 dispositivo fol, por isso, bastante criticado pela doutrina, já que promoveu a positivaçäo equivocada de uma confusăo sen justificativa entre exclusão da persecução penal e exclusäo do crime (MAGALHÃES, 1968, p. 114).
} 
de que, ao consentir com a lesão, tornava-se partícipe da causa do dano (DE CUPIS, 1979, p. 270), renunciando, assim, à tutela estatal; nesta hipótese, em última análise, acaba-se por incluir a causa justificadora em estudo dentre aquelas relacionadas à culpa do ofendido, posição hoje não mais aceita pela doutrina hodierna (VARELA, 1998, p. 553).

A confluência entre os dois institutos pode ser encontrada de forma bastante presente em alguns pandectistas, refletindo-se, da mesma forma, em parte das doutrinas francesa e italiana ${ }^{14}$ e no tratamento que a jurisprudência inglesa dava a casos desta natureza (PRATA, 1985, p. 156), ao que não ficou alheio o pensamento jurídico português. Dito tratamento indiferenciado, seguindo nesta linha de direito comparado, chegou até mesmo a ser verificado, no plano legislativo, dispondo, U.g., o Código das Obrigaçōes suiço, em seu artigo 44 , n. 1 , que o consentimento impuro seria forma de manifestação de culpa própria (PROENÇA, 1997, p. 613).

A evolução do pensamento civilista, todavia, permitiu verificar a inadequação deste posicionamento. Para tanto, tendo em conta os pressupostos antes já traçados acerca do que representa o consentimento do lesado, a simples verificaçã́o dos contornos dados pela doutrina acerca da figura da culpa exclusiva ou concorrente da vítima basta a bem diferenciar os institutos.

A culpa do lesado encontra a sua solução preponderante no campo de análise da causalidade do dano, já que "só deve ser ponderada na media em que o seu comportamento seja concausa do dano, ou seja, é necessário que o dano seja causado pelo agente ou pelo lesado" (LOURENÇO, 2006, p. 262). Desta feita, verificar-se-â, quando restar demonstrado, que uma determinada conduta praticada pelo ofendido fol a causadora do dano ou para ele concorreu, paralelamente

\footnotetext{
"4 Segundo José Carlos Brandão Proença (1997, p. 612), dentre os pandectistas que seguiram esta linha, podese citar a obra de Demelius. Já nas doutrinas francesa $e$ italiana, respectivamente, o autor alude às obras de Desshizeaux, Esmein e Le Toumeau e Chironi e Pacchioni como exemplos desta confluência entre consentimento e culpa.
} 
àquela impetrada pelo ofensor. O mesmo se verifica na dou trina brasileira, para a qual, "com a culpa exclusiva da vítima, desaparece a relação de causa e efeito entre o dano e seu causador" (VENOSA, 2006, p. 44).

Daí porque se afirmar a atecnia do tratamento uniforme de ambas as figuras, já que relacionadas a pressupostos diversos. Como dito, enquanto a culpa da vítima guarda relação com a causalidade (plano fático da aferição dos pressupostos do dever de indenizar), o consentimento do lesado insere-se na esfera do plano jurídico dos mesmos pressupostos, pois relativo à ilicitude (CORDEIRO, 1997, p. 423).

Apresentadas as diferenciaçôes até aquí postas, 15 o que visou bem delimitar o âmbito de incidência da figura jurídica objeto da presente investigação, cumpre tratar acerca da sua regulação e operatividade no ordenamento português e a sua possibilidade de transposição à ordem jurídica brasileira.

\section{O Regime Geral de Justificação pelo Consentimento}

O consentimento do lesado como causa de exclusão da ilicitude, em Portugal, encontrou tratamento no Código Civil de 1966, em seu artigo 340 , o qual estatui que "o ato lesivo dos direitos de outrem é lícito, desde que este tenha consentido na lesão". A matéria, da mesma forma, mereceu regramento, no âmbito criminal, pelo Código Penal de 1982, que, em seus artigos 38 e $39,{ }^{16}$ previu de forma expressa a figura do consentimento do ofendido, inclusive na sua

\footnotetext{
is For questốes de estrutura da exposiçäo e visando uma methor sistematizaçäo da pesquisa, a figura hoje ja apontada pela doutrina sob o nome de "assunçào de riscos", a par das discussóes acerca da sua autonomia em relaçào ao regime do consentimerito do lesado, ao nuvés de ser tratada neste item relativo às figuras afins, será abordada no item 41 , junto com o consentimento tácito.

${ }^{16}$ Artigo 38. (Consentimento) 1 . Alem dos casos especialmente previstos na lei, o consentimento exclui a ilicitude do fato quando se referir a interesses juridicos livremente disponiveis e of facto nâo ofender os bons costumes. 2. O consentimento pode ser expresso por qualquer meio que traduza uma vontade séria, livre e esclarecida do titular do interesse juridicamente protegido, e pode ser livremente revogado até à execuçăo do facto 3 . O consentimento só é eficaz se for prestado
} 
modalidade presumida, como hipótese de justificação do fato típico.

Ao contrário, no ordenamento brasileiro, a mesma causa de justificação não mereceu atenção legislativa expresso, seja no revogado Código Bevilaqua, seja no hoje vigente Código de 2002. O mesmo ocorre em material penal, sustentando parte da doutrina (TOLEDO, 1984, p. 128), inclusive, que esta omissão legislativa seria intencional dado o caráter "evidentemente supérfluo de um dispositivo a respeito.

Nâo obstante esta opção, fundada em suposta desnecessidade de regulamentação do tema, nada tem impedido a doutrina brasileira ${ }^{17}$ de aceitar o consentimento do lesado como causa supralegal de justificação do ato danoso. Para tanto, o fundamento seria o mesmo que a fez constar no Código Civil portuguềs: objetivando o direito a tutela de uma gama significativa de interesses privados do sujeito, a disponibilidade sobre eles permite que seja excluída a ilicitude de ato lesivo direcionado contra os referidos, desde que precedido de aquiescência do titular.

Por evidente, a ausência de regulamentaçâo positiva no direito brasileiro restou por acarretar, a par do reconhecimento da sua existência e aplicaçăo, uma certa desestrutura da matéria que, mesmo tendo inegável importância, nâo apresenta tratamento autônomo e sistematizado, seja na doutrina, seja na jurisprudência. Assim, do ponto de vista metodológico, a presente investigação, ao apresentar o tema em ambos os

por quem tiver mais de 14 anos e possuir o discemimento necessário para avaliar 0 seu sentido e alcance no momento em que o presta. 4 . Se o consentimento näo for conhecido do agente, este é punivel com a pena aplicável à tentativa. Artigo 39. (Consentimento presumido) 1. Ao consentimento efectivo é equiparado o consentimento presumido. 2 Há consentimento presumido quando a situação em que o agente que actua permitir razoavelmente supor que o titular do interesse juridicamente profegido teria eficazmente consentido no facto, se conhecesse as arcunstânctas $\mathrm{e}$ que este e praticado:

${ }^{17}$ Neste sentido, o magistério de Orlando Gomes (1987, p. 419), Francisco Amaral $(2000$, p. 535) e Rui Stoco (2007, p. 223), dentre outros. Na doutrina penal, exemplificativamente, merecem registro os ensinamentos de Heleno Cláudio Fragoso (1994, p. 192) e Francisco de Assis Toledo (1984, p. 128). 
ordenamentos, buscará destacar a experiência portuguesa no trato do assunto e, na seqüência, a compatibilidade da sua transposição ao ordenamento brasileiro, aferindo-se, ao cabo, a atual necessidade ou não de eventual regulamentação legislativa a respeito.

Como antes referido, o Código Civil português, na sua parte geral, no capítulo destinado às disposições gerais do exercício e tutela dos direitos, apresenta diversas hipóteses de exclusáo da ilicitude, dentre elas o consentimento do lesado, asseverando ser lícito o ato nesta condiçâo cometido ${ }^{18} \mathbf{E}$, pois, consagração expressa do princípio in volenti non fit iniuria, legitimando a possibilidade de o titular da proteção jurídica dela dispor, renunciando-a ațravés do seu consentimento em relaçāo ao ato lesivo.

O primeiro questionamento que se põe, assim, está relacionado à forma como ele se expressa. Segundo Karl Larenz (1959, p. 590), não se trata, aqui, de um consentimento no sentido do $\S 183$ do $\mathrm{BGB},{ }^{19}$ nem da aceitação de um negócio jurídico, ${ }^{20}$ mas da autorização para a realização de açõ̃es positivas que restam por repercutir na esfera jurídica do

\footnotetext{
António Menezes Cordeiro (2007b, p, 455), ao tratar da sua ínserção na parte geral do Código, no capítulo dedicado à tutela privada, define o consentimento do lesado como "uma manifestação de liberdade subjacente à tutela privada", mencionado, ainda, tratar-se de regra típica de responsabilidade civil, pelo que "a sua solene inclusão na parte geral do Código faculta mais un dos impressionantes equivocos imputáveís à classificação gemanica pura".

ig Segundo o referido dispositivo do Código Civil alemäo, "I. Se a eficácia de um negócio jurídico unilateral que se tenha celebrado frente a outro, depende do consentimento de um terceiro, a concessão como a denegação do consentimento, pode declarar-se tanto frente a uma como frente a outra parte. 2. O consentimente não requer a forma estabelecida para o negócio jurídico. 3. Se um negócio jurídico unilateral, cuja eficácia depende do assentimento de um terceiro, celebra-se com o consentimento do terceiro, aplicam-se respectivamente as disposiçónes do parágrafo 11, números 2 e $3^{\prime \prime}$ (MEDICUS; 1995b; p. 870)

${ }_{20}$ A referência de Karl Larenz à impossibilidade de simples aceitação de um negócio jurfdico deve-se, por certo, à negação do pensamento defendido por Emst Zitelmann, autor da já teferida Teoria do Negócio Jurídico, para o qual a justificação da conduta praticada com base no consentimento do lesado representava uma concessáo negocial para que o autor do dano realizasse a conduta típica. Sobre o tema, inclusive com seus desdobramentos em matéria de teoria do crime, ver o magistério de Edmundo Mezger (1946, p. 398 e ss). Em língua portuguesa, Délio Magahäes (1968, pp. 108-110).
} 
autorizante, o que lhe dá contornos de declaração de vontade análoga às negociais.

Exatamente por isso é que o pensamento dominante tem definido-o como um ato unilateral, não obstante encerre inegável natureza negocial, já que o seu titular poderá estabelecer os limites e o alcance desta autorização (CORDEIRO. 2007b, p. 456); nas palavras de Ludwig Enneccerus (1935a, p. 638), pois, "é um negócio jurídico unilateral". ${ }^{21}$

Assim é que o consentimento que aqui interessa exprimido por meio de autorizaçăo, ato pelo qual o titular da proteção jurídica permite que terceiro intrometa-se na sua esfera particular (JORGE, 1995, p. 270). Terá, em razão disso, natureza integrativa, na medida em que não cria direitos por si só ao destinatário do consentimento; se assim nẫo fosse, em havendo predomínio de uma natureza constitutiva, não haveria que se falar em autonomia da figura jurídica em questão, pois representaria mero exercício de um direito por parte do lesante, nascido a partir da autorização concedida pelo lesado (JORGE, 1995, p. 270).

Da mesma forma, tendo natureza negocial, para que possa excluir a ilicitude, exigir-se-á daquele que consente legitimidade, capacidade de gozo e capacidade de exercício para exprimi-lo válida e eficazmente (CORDEIRO, 2007b, p. 456; BRIZ, 1962, p. 84), além de vontade corretamente formulada e exteriorizada (JORGE, 1995, p. 271), o que poderá ser feito por qualquer meio (FERREIRA, 1988, p. 176), salvo quando a lei exija algum em especial. ${ }^{22}$

\footnotetext{
z: Conforme Carlos Alberto da Mota Pinto (2005, p. 385), entende-se por negócio jurí dico unilateral aquele em que há uma unica vontade negocial manifestada ou, pelo menos, se forem várias; serão paralelas, formadoras de um grupo unico; por regra, afetam apenas a pessoa que os pratica oú, como no caso da autorização, afetam outra pessoa, mas com a finalidade de atribuir-the uma faculdade ou uma posiçä preferencial. ${ }^{22}$ Assim já reconheceu a jurisprudência portuguesa ao assentar que "[o] consentimento do lesado não exclui a ilicitude de um acto, como a transmissăo do direito de propredade sobre imóveis, que careça de escritura pública, quando falte a forma legal exigiven (PORTUGAL. Tribunal da Relação do Porto. Recurso n. 9350409. Rel. Des. Antero Ribeiro. Julgado em: 11 out. 1993. Disponivel em: <http//www.dgsi pt> Acesso em: 14 abr. 2008).
} 
Quanto à capacidade para consentir, independentemente da antes destacada inegável natureza negocial do ato, nāo coincidirá obrigatoriamente com aquela exigida para a generalidade das manifestações negociais. Para tanto, a este respeito, tem-se destacado que, em algumas hipóteses, bastará à incidência da causa de exclusão em exame a mera capacidade natural, desde que relacionada a disposiçōes patrimoniais de pequena importância. ${ }^{23}$

No que toca à vontade, fazem-se necessárias algumas referências, as quais, a par de interesse geral no presente momento, adquiriräo contomos ainda mais significativos quando do tratamento acerca do consentimento tácito. Isso porque, para que o sujeito possa consentir em uma lesão a interesse protegido seu, deve ter plena ciência do que isso efetivamente representará, das suas reais consequếncias e efeitos, a fim de formar sua vontade de forma livre e desembaraçada. Em outras palavras, o consentimento haverá de ser seriamente emitido e com pleno conhecimento da situação de fato (BRIZ, 1962, p. 84).

Os deveres de informação adquirem, aqui, portanto, significativa relevância, já que o conhecimento acerca dos elementos que envolvem o ato a ser praticado precisam ser plenamente compreendidos por aquele que manifestará seu consentimento; só após ser cientificado a respeito poderá ponderar os fatores envolvidos, os eventuais riscos, os custos

\footnotetext{
${ }_{23}$ Esta é a posiçāo defendida, dentre outros, por Teresa Pizarro Beleza (1980, p. 51) e Manuel Cavaleiro de Ferreira (1988, p. 177). A dispensa da capacidade negocial. como antes destacado, năo é irrestrita. A este respeito, observa Femando Pessoa Jorge (1995, p. 271) que o limite para tanto será a regra do artigo $127, n$. 1 , alínea ${ }^{~} \mathrm{~b}$ ", do Código Civil português, segundo o qual "[o]s negócios jurídicos próprios da vida corrente do menor que, estando ao alcance da sua capacidade natural, só impliquem despesas, ou disposiçôes de bens, de pequena importância”. Daí que, segundo o autor, será relevante o corisentimento justificador do menor - que năo possuicapacidade negocial -- quando permite que terceiro utilize um brinquedo seu ou coma um alimento que the pertença, sendo irrelevante, na mesma linha, o consentimento dessa mesma criança para que outrem, U.g., utilize ou destrua um prédic que the pertence. Mesmo a mingua de igual regulaça no Código Civil brasileiro, esta posiçäo pode ser de igual modo aplicada nạuele pais por força da incidência da doutrina dos atos existenciais, alicerçada em fundamento tdêntico ao que serviu de hase ao artigo $127, n$. $I$, aliena " $b$ " do congênere português.
}

Cadernos do PPG em Direito UFRGS, Porto Alegre, $\vee .6$, n. 7 e 8, p. 51-100, 2007. 
e benefícios que lhe advirão do agir que seu consentimento pode legitimar. Em assim não sendo, poder-se-á verificar a incidência das diversas modalidades dos vícios da vontade, dentre eles o erro, o engano ou a coação (FERREIRA, 1988, p. 176).

Após prestado, o consentimento é, de regra, revogável, ${ }^{24}$ salvo se houver manifestação expressa no sentido de que assim não seria possivel ou - e principalmente - se a irrevogabilidade derivar da finalidade com que foi dado, em especial quando relativo a atos de disposiçăo patrimonial e isso tenha sido feito no interesse do agente que age acobertado pela excludente (ENNECCERUS, 1935b, p. 387). Assim, por exemplo, em anuindo o proprietário que se utilize bem seu, pode voltar atrás em relação a este consentimento até o momento em que realizado o ato lesivo, não podendo, após isso, já se tendo verificado a ação danosa sob o manto da excludente de ilicitude, pretender revogar o consentimento dado ${ }^{25}$ e obter indenização por danos eventualmente sofridos. ${ }^{26}$

A disciplina relativa à forma como o consentimento expressa-se até aqui esboçada, por decorrer das regras gerais dos sistemas jurídicos e não de regulamentação específica, mostra-se compativel com os ordenamentos jurídicos português e brasileiro, os quais, nestas questōes, restam por partilhar a maneira como a matéria pode ser vista.

\footnotetext{
24 Sobre a revogabilidade do consentimento, assinala Claus Roxin (1997, p. 535), em ponderaçào perfeltamente transponível à responsabilidade civil, que esta năo pode ser uma mudança de vontade meramente interna, exigindo manifestação exterior neste sentido.

${ }^{25}$ Esta, aliás, no que toca ao tratamento criminal dispensado à matéria, é a expressa disposição do artigo 38 , n. 2, parte final, do Código Penal portugués.

ż Situaçăo semelhante foi enfrentada pela jurisprudencia portuguesa, cujo precedente restou assim sumariado: "Autorizada pelos proprietănos do quintal a ocu-pação de com vista ao depósito dos materiais necessétios à obra edificada por outrem ${ }_{*}$ a circunstância de o mesmo não poder ser culivado e não produrir aquilo para que era apto não gerana o direito de indemnização dos primeiros, em virtude de operar a causa de justificação do ilicíto consentimento do lesado a que se reporta o artigo $340^{\circ}$, n. I, do Código Civil (PORTUGAL. Supremo Tribunal de Justiça. Recurso de Revista n. 04B2751. Rel Cons. Salvador da Costa. Julgado em: 23 set. 2004. Disponivel em: <hitp//wwwdgsipts. Acesso em: 17 fev. 2008).
} 
Ainda, merecem referência as hipóteses em que a lei considera o titular do direito obrigado a consentir ou dispensa este consentimento para fins de justificação do ato, como ocorre, v.g., respectivamente, nos casos de passagem ou utilização de determinado prédio para fins de manutenção no edifício vizinho (artigo 1349, n 1, do Código Civil português e artigo 1313, inciso I, do Código Civil brasileiro) ou nas hipótese de exposição ou reprodução de imagem de pessoa pública, ressalvadas as limitaçoes legais (JORGE, 1995, p. 271). Nestes casos, em verdade, a exclusẫo da ilicitude decorre diretamente da lei, seja quando determina o consentimento, ${ }^{27}$ seja quando o dispensa, não se encontrando relevância jurídica fundamental na aquiescência do lesado para fins de justificação do ato.

Ao cabo, também no que toca à manifestação do consentimento, é digno de nota o momento em que ela se dá, verificando-se a sua relevância para fins de exclusẩo da ilicitude.

A doutrina majoritária ${ }^{28}$ costuma assinalar que, para fins de justificação do ato danoso, o consentimento do ofendido deve ser prestado em momento arterior à sua prática. Em assim não sendo, a operar-se a aquiescência posteriormente à lesão, teria o simples efeito de renúncia à pretensão indenizatória, relacionada tão-só ao direito secundário (diritto secondario) decorrente do ilícito.

Em suma, seja em Portugal, seja no Brasil, se a concordância do ofendido afasta o dever de abstenção de atuação na esfera jurídica alheia, a permitir a conduta do lesante, apenas o consentimento anterior a esta poderá ser excludente de ilicitude, fazendo com que, após praticada, tendo-se já revestido de contrariedade ao direito, possa o titular da pretensão ressarcitória apenas abrir mão do seu exercício; até porque,

\footnotetext{
${ }^{27}$ Jorge Ribero de Faria (1991, p. 450) nomina estas hipöteses como "consentímento coactivamente prestado".

28 Neste sentido, posicionam-se Mário Júlio de Almeida Costa ( 991, p. 501), João de Matos Antunes Varela (1998, p. 552), Adrano Vaz Serra (1959, p. 107), Adriano De Cupis (1979, p. 270), Jaime Santos Briz (1962, p. 85) e Claus Roxin (1997. p. $525)$, dentre outros.
} 
como de regra, as causas justificativas devem verificar-se antes do fato e năo após.

Fernando Pessoa Jorge (1995, p. 273 e ss) manifesta posição divergente, questionando a impossibilidade de considerar-se o consentimento posterior mera renúncia à indenização. Para tanto, sustenta que a conduta ilícita deve ser vista como un todo, não sendo razoável que o ato continue sendo considerado antijurídico - com todos os efeitos que lhe são próprios e não apenas com relação à irresponsabilidade civil do agente - mesmo após consentímento da vítima, que, por isso, poderia importar na produçâo de efeitos retroativos. ${ }^{29}$ Em não se aceitando a retroatividade para fins de exclusão da ilicitude, sustenta, ainda, posição intermediária segundo a qual o consentimento deveria implicar renúncia não apenas da indenização, "mas de todos os direitos que adviessem do caráter ilícito da lesầo" (JORGE, 1995, p. 274).

A preocupação apresentada mostra-se compreensível. porquanto se o ofendido, em momento posterior, termina por ratificar o ato empreendido pelo lesante, năo se mostraria adequado que se mantivessem todos os efeitos da ilicitude, exceto o dever de indenizar em relação ao qual a aquiescência seria considerada renúncia.

Permitir, todavia, a retroatividade dos efeitos do consentimento contraria a lógica $\mathrm{e}$ a melhor técnica, porquanto, nesta hipótese, quando o consentimento é dado, do ponto de vista jurídico, a conduta já se revestira de ilicitude, uma vez que a incidência da norma tuteladora é imediata (satisfaz, desde logo, o suporte fático hipotético) ${ }^{30}$ Assim, aceitar a tese da retroatividade implicaria, como já dito, contrariar pressuposto elementar de direito segundo o qual as causas justificadoras

\footnotetext{
${ }_{29}$ Consoante assinala Fernando Pessoa Jorge (1995, p. 273), "a retroatividade șó é, evidentemente, possivel num plano ideal, no sentido de que a lei reconhoce os efeitos de certo acto como se este tuesse deteminada qualidade que historicamente não teve".

30 Tanto que, neste particular, a doutrina costuma subdividir o assentimento em consentimento, quando prestado anteriormente ao ato a que se refere, e em ratificação, quando posterior (ENNECCERUS, 1935b, p. 387).
} 
operam-se sempre antes da prática do ato a que dizem respeito, porquanto, se verificadas depois, a ilicitude já está presente.

A solução tecnicamente mais correta, diante da natureza das figuras envolvidas, parece ser aquela que exige que o consentimento seja anterior ao ato, pois, se posterior, pelas razões já apresentadas, terá efeitos de mera renúncia da indenização. Nada impede, contudo, até mesmo por se mostrar mais equânime, a adoção da via alternativa antes apontada na doutrina de Fernando Pessoa Jorge: se é certo que a aquiescência posterior nâo pode ser tida como simples renúncia, não podendo, da mesma forma, retrotrair seus efeitos para fins de justificar o ato danoso, porque este já nasceu ilícito, é razoável que se entenda que implicará, assim, renúncia não só ao dever de indenizar, mas a todos os reflexos que o ato porventura venha a produzir no mundo jurídico, desde que estejam sob a disponibilidade do agente.

\section{Os Limites da Justificação pelo Consentimento}

Se é certo que o direito concede disponibilidade ao titular da proteçấo por ele conferida, fundamento este da justificação pelo consentimento do ofendido, hipóteses verificar-se-ão em que, diante da natureza dos interesses postos em causa, esta aquiescência não bastará a excluir a ilicitude do fato danoso.

Diante disso é que serâo impostas uma série de limitaçôes à relevância justificadora da anuência do titular do interesse em relação à conduta a que se refere, o que decorrerá, por assim dizer da natureza indisponível da tutela conferida a diversos bens jurídicos.

Atento a isso, o Código Civil português, em seu artigo 340 , n. 2, dispöe que "o consentimento não exclui, porém, a ilicitude do acto, quando este for contrário a uma proibiçăo legal ou aos bons costumes". Criou, desta forma, dupla limitaçăo à excludente em estudo, fazendo com que năo possa surtir efeitos nas hipóteses antes referidas. 
Sem prejuizo de ter tratado a lei portuguesa de duas situaçōes concretas - proibição legal e contrariedade aos bons costumes -, como já dito, a limitaçấo dos efeitos do consentimento do lesado, em última análise, coincide com as hipóteses de indisponibilidade do direito relativa ao seu conteudo em $\mathrm{si}^{31}$ sendo que o teor do preceito legal apenas representa a concretização dessa impossibilidade. ${ }^{32}$

$E$ isso se dá até mesmo em razâo da própria origem do instituto, porquanto se a lei năo confere liberdade (rectius disponibilidade) ao sujeito para abrir mão daquela proteção por ela concedida, não poderá a sua anuéncia implicar exclusăo da ilicitude nos casos em que esta năo exista.

Por essa razão é que, mesmo não havendo previsăo expressa sobre a justificação pelo consentimento do lesado no direito brasileiro, a mesma limitação decorrente da

\footnotetext{
3: Em matéria de disponibilidade do direito, cumpre registrar que a limitação diz respeito não só ao seu conteưdo, mas, támbérn, à sua titularidade, sendo necessário que, para dispor, o lesado seja titular da integralidade do direito, por decorrencia logica do principio geral de quem nínguém pode dispor daquilo que não tem.

${ }^{32}$ Esta é a posiçăo defendida, dentre outros, por Jorge Ribeiro de Faria (1991,p. 449), segundo o qual "[a] irrenumciabilidade pode derivar tanto de uma proibiçăo legal como dos bons costumes". No mesmo norte, Karl Larenz (1959, p, 590). Com sistematraçăo diversa, Fernando Pessoa Jorge $(1995, \mathrm{p}, 271)$, quando trata da primeira hípotese do n 2 do artigo 340 do Código Civil português (proibiçâo legal), faz associaçáo entre esta $a$ indisponibilidade do direito dando a entender que a limitacăo decorrente da violacáo dos bons costumes não guardaria com ela -.. indisponibilidade relaçấ, ou sela, nestes casos, o titular até poderia ter disponibilidade sobre os interesses protegidos 0 que permitiria o consentimento, mas como essa disposicao resta por violar os bons costumes, surge a limitação à sua relevância. Fste nato aparenta ser o melhor entendimento, porquanto seja a proibica legal, seja a limitaça pelo respeito aos bons costumes, ambas conduzen, en última análise, a uma indisponibilidade do direito que năo precisa decorrer necessariamente da lei, mas do sistema como um todo. Tanto que, nos ordenamentos nos quais năo há regulação da materia, como no brasileiro, seja a indisponibilidade por afronta a proibiçóo legal seja por afronta aos bons costumes, costumam, de igual modo, ser reconhe cidas. Dai que as impressöes de Antóno Menezes Cordeiro $(2007 \mathrm{~b}, \mathrm{p} .456)$ a respeito do confronto entre a disponibilidade em si ou aguela decorrente da forma como ela se manifesta parecem mais adequadas do ponto de vista da técnica. Sezundo o autor, é necessario distinguir a indisponibilidade de um direito dos casos em que; não obstante haja disponibilidade, 0 consentimento seja inefica $z_{\text {, pois }} 0$ ato, em concreto, eque contrarta probição ou os bons costumes. Até porque, como aponta, em ambas as hipóteses, o consentimento manifestado sera irrelevante para fins de exclusão da ilicitude.
} 
indisponibilidade resta por ser-lhe aplicada, ${ }^{33}$ pois decorrente dos preceitos gerais do próprio ordenamento jurídico, ou melhor, da própria natureza dos bens jurídicos por ele tutelado.

Daí a pertinência de que a aferiçăo dos limites do consentimento do lesado seja criteriosa e feita com base nas peculiaridades do caso concreto, objetivando bem se perceber as reais hipóteses em que a concordância adquire rełevância jurídica em relação ao juízo de ilicitude. Ou seja, perceber não só os casos em que o consentimento verse sobre direitos indisponíveis, mas também aqueles em que, não obstante haja disponibilidade, o consentimento seja ineficaz porque, ele próprió, contrarie proibição legal ou os bons costumes (FERREIRA, 1988, p. 177).

A par das ponderaçốes de ordem geral até aqui traçadas, merecem exame as hipóteses específicas trazidas pela lei portuguesa, até mesmo para verificar a sua adequação como forma de regulamentação do tema.

No que toca à restrição decorrente de proibição legal, o exemplo que tem sido costumeiramente trazido pela doutrina (LEITAO , 2000, p. 312) diz respeito à irrelevância de alguém consentir com a própria morte, uma vez que a vida é bem jurídico protegido nos ordenamentos jurídicos por meio da criminalização da conduta do homicídio. ${ }^{34}$

\footnotetext{
3 Esta é a posição da doutrina brasileira (AMARAL, 2000, p. 535). O mesmo se verifica na doutrinna espanhola, pais onde, a exemplo do que ocorre no Brasil, também năo tem regulamentaçăo expressa do tema (BRUTAU, 1983, p. 85; ESTEVILL, 1995, p. 534).

3a Năo obstante a intensa frequência com que dito exemplo é empregado para demonstrar hipótese de contrariedade à proibiçầo legal nào se pode deixar de fazer referência a interessantes consideracooes acerca da (in)disponibilidade do bern jurí dico vida feitas pela doutrina criminal. Neste particular, observa Teresa Pizarro Beleza ( 1980, p. 516$)$ que o fato de o legislador năo criminalizar o suicídio (obviamente que quando falhado ou tentado) e um indicativo de que a indisponibilidade da vida humana é relativa. De igual modo, ainda segundo a autora, a puniçâo diferenciada entre as condutas de homicidio e de auxiljo ao suicídio bem demonsiram que mesmo não tendo condão de excluir a ilicitude da conduta do agente, o consentimento do ofendido na segunda hipótese, não é de todo irrelevante para o direito penal. Em sentido contrário, Manuel Cavaleiro de Ferreira (1988, p. 175) sustenta a indisponibilidade absoluta do bern jurfdico vida.
} 
Aqui, desde logo, se pode perceber que o direito penal adquire função relevante na delimitação do território da disponibilidade do titular da proteção jurídica, havendo de distinguirem-se os casos em que o consentimento não afasta a incriminação daqueles em que resta por obstar a incidência da norma penal, seja porque pode funcionar como causa de justificação na esfera criminal, seja porque o não consentimento pode ser elemento do tipo (JORGE, 1995, p. 272; ROXIN, 1997, p. 528; BELEZA. 1980, p. 513).

$\mathrm{Na}$ primeira hipótese, resta afastada a incidência da exclusâo da ilicitude em comento, pois o consentimento é irrelevante quanto à incriminação, não podendo obstar a proibição legal que dela decorre; na segunda, quando por ele próprio já for excludente na ceara penal ou quando o tipo

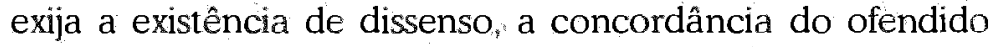
com o ato danoso poderá produzir a sua justificaçăo na esfera cível.

Ainda sobre a restrição decorrente da lei, já saindo do campo de atuação do direito penal, é de ser observado que “[a]s hípótese de proibição legal são bastante mais extensas do que poderia parecer, numa visão superficial" (CORDEIRO, 2007b, p. 456), nelas se incluindo não só aquelas relativas aos direitos de personalidade e aos direitos de família, de um modo geral indisponíveis, mas também outras pontuais verificadas em matéria de direitos obrigacionais e reais. ${ }^{35}$

Quanto à restriçâo decorrente dos bons costumes, o exame da relevância do consentimento apresenta-se mais controvertido, justamente em razão da dificuldade de precisar os contornos do conceito jurídico indeterminado em questão. ${ }^{36}$

\footnotetext{
${ }^{35}$ Neste particular. António Menezes Cordeiro (2007b, p. 456) cita, por exemplo, os artigos 809, 836, n. 1, e 942, n. 1, todos do Código Civil portugues:

3* A par da sua diticuldade, a doutrina é praticamente unânime em apontar a existência desta limitação pelos bons costumes, nâo obstante poưcos tratem acerca dos melhores critérios para operacionalizar a sua aplicação. Neste sentido, Ludwig Enneccerus (1935a, p. 638), José Puig Brutau (1983, p. 85), Luis Diez-Picazo (2000, p. 304) e Jaime Santos Briz (1962, p. 83), dentre outros:
} 
A partir da sua evolução, desde a noção romana de mores até a inserção no direito codificado contemporâneo, ${ }^{37}$ amplos e variados foram os contornos dados à expressão "bons costumes" (CORDEIRO, 2007a, p. 699). Na atualidade, contudo, estas dimensões tem-se reduzido, podendo destacar, nomeadamente no campo das tegras de comportamento sexual e familiar, um reconhecimento pelo direito civil da sua normatividade, a par de nấo a referir de modo expresso..$^{38} \mathrm{~A}$ estes dois campos destacados - comportamento sexual e familiar - podem ser associadas, de igual sorte, as regras deontológicas afetas a dadas profissões, ${ }^{39} \mathrm{em}$ que também poderá ser verificada uma certa normatividade atribuída aos bons costumes.

Daí que, com freqüência, será possível encontrar na doutrina a delimitaçăo do conteúdo do conceito em questấo através de referência a "concepções ético-jurídicas dominantes na coletividade" (LIMA; VAREIA, 1982, p. 397), sendo, pois, conceito situado historicamente..$^{40}$ Por isso, será suscetivel a influência direta do que a sociedade vive, das experiências

\footnotetext{
37 São várias as referências encontradas aos bons costumes, tanto no Código Civil português quanto no congênere brasileiro, podendo-se citar, exemplificativamente, naquele, os artigos $271, n$. $1,280, n .2,334,340, n .2,465$, alinea, " $a$ ", $967,1.422$, n. 2 , alínea "b", $2.186,2.230$ e 2.245 , e, neste, os artigos $12,122,187,1.336$, inciso IV, e 1.638, inciso III. A freqüencia mais evidente na lei civil portuguesa em comparaçăo à brasileira prôvavelmente deva-se aos quase quarenta anos que separam a promulgaça de ambos os Códigos, bem evidenciando a reduçäo do campo operativo do concelo jundicamente indeterminado em questäo ao longo dos tempos, $O$ seu objetivo, entretanto, na maloria dos casos, guarda relação com a limitação da autonomia privada (CORDEIRO, 2007c, p. 1211).

${ }^{38}$ Neste particular conforme observa António Menezes Cordeiro (2007a, p. 709), "[o] Direito Civil reconhece regras a que empresta um conteúdo jurídico, mas que, por razöes de circunspecta tradição, nunca refere de modo expresso. Estâo nessas condiçoes as regras de comportamento sexual e familar que, no fundamental, têm o seguinte conteúdo: năo são admissiveis negocios juridicos - excluídos os atos próprios do Direito da família e que a lei tipifica - que tenham por objecto prestaçöes que envolvem relaçöes familiares ou condutas sexuais".

${ }^{39}$ Consoante leciona Jorge Sinde Monteiro (1983, p. 464); "os bons costumes năo devem ser vistos apenas pelo prisma de uma ética individual, antes de abranger o setor de uma ética de ordenação ("princípios de boa ordenação de uma sociedade'), em que se integram os deveres fundamentais das diversas profissoes".

${ }^{4}$ Discorrendo sobre o princípio da boa-fé, mas em digressäo que se mostra, da mesma forma, pertinente no que toca aos bons costumes, Judith Martins-Costa
} 
que são verificadas no seu corpo social, apontando para valores inegavelmente consensuais e alargados, até mesmo como exigência de uma sociedade pluralista (FRADA, 2004, p. 843) e de um Estado Democrático de Direito.

Assim é que sua relação com os comportamentos humanos, nomeadamente como fonte de limitação da autonomia privada e, bem assim, de ilicitude, justifica-se no fato de que inobstante o ato consentido surja como um ato pessoal, tem relações necessárias com a coletividade. ${ }^{41}$

Por tudo isso, ter-se-á que a limitação do consentimento pelos bons costumes traz, no seu âmago, um intuito de proteção de um interesse de mais amplo espectro, baseado no senso comum coletivo vigente no corpo social, sendo que a sua própria essência conformará os limites da autonomia que o direito confere no marco da própria esfera do interesse autorizante (ESTEVILL, 1995, p. 534).

O grande problema surge justamente ai, porquanto, para concretizar o conceito em debate, na busca da proteção destes ditos valores difusos, não raro lança-se mão de preceitos de ordem moral, ${ }^{42}$ o que se constitui em celeuma de

(2003, p. 79) esclarece que " $\theta$ caráter situado do conhecimento e da compreensão, própio dos fenômenos culturais, recobre a ciência jưídica, na medida em que essa constitui o resultado de um processo extraordinariamente laborioso e complexo de integração entre fatos e valores. Daí que toda a ciência jưtidica 'si constituice contestualmente: E se é constituida contextualmente, é porque la estrutura del Vorverständnis coglie la storicità ela localizzazione come dimensione intrinseche al conoscere" ${ }^{3 n}$.

47 Daí que, segundo parcela da doutrina, o que se objetivaria com a limitaçäo pelos bons costumes é não permítir que uma açầ individual possa afetar toda a sociedade ou, em outras palavras, especificamente no que toca a excludente de llicitude em exame, impedir a legitímaçào de danos fundados na "inmoralidad" sob o fundamento de que năo se pode aceitar que o consentimento da vítima possa excluir a ilicitude de fatos que "contravienen las más elementares nomas de la convivencia social y son esa clase de prejuicios a los que el Derecho niega la possibilidad de que el mero consentimiento de la victima odel que los padece les exonere de su anijuricidad" (ESTEVIL, 1995 , p. 534 )

${ }^{42}$ Isto é o que se observa, u.g. nas liçöes de Manuel Cavaleiro de Ferreira (1988. p. 176), em especial quando o autor faz mençăo à "reprovaçäo pela moral ou pela opiniäo comum (o sentimento geral sobre a moralidade $[\ldots]$ )". O mesmo também pode ser verificado nas obras de Karl Larenz (1959, p. 591) e Luis Fascual Estevill (1995. p. 534). 
difícil solução tendo em conta que, em sociedades plurais como as hoje em dia verificadas, não é possível pretender-se consenso no que toca aòs princípios relacionados à moral privada susceptíveis de garantir a segurança jurídica (ROXIN, 1997, p. 530). Nisso reside a dificuldade de delimitação deste senso coletivo global que marcaria os contornos do conceito de bons costumes.

Tendo em conta estes marcos teóricos, o exemplo mais freqüentemente encontrado na literatura jurídica (LEITÃO, 2000 , p. 312) envolvendo a relaçầo entre consentimento do lesado e bons costumes diz respeito à impossibilidade de a aquiescência do ofendido justificar práticas sado-masoquistas causadoras de lesões. Não há, contudo, consenso a respeito, existindo parcela da doutrina (ROXIN, 1997, 530) que sustenta, nestas hipóteses, de modo contrário ao antes referido, a possibilidade de o consentimento justificar o ato lesivo, o que bem adianta a controvérsia existente acerca do tema.

É notório que na área relacionada a práticas sexuais, a progressividade da aceitaçáo coletiva [ou seria melhor dizer da indiferença coletiva] das mais variadas tendências deve ser levada em conta, sendo certo que, para a delimitação do conceito de bons costumes, não há como se lançar mão de contornos muito rígidos acerca dos usos aceitáveis em sociedade. Daí porque propor Claus Roxin (1997, p. 530) que qualquer limitação por afronta aos bons costumes somente tenha lugar quando se possa depreender do próprio ordenamento jurídico uma clara reprovaçăo legislativa em relação a determinada conduta, a qual, ainda, para tanto, deverá implicar menoscabo de bens jurídicos que não estâo submetidos à disposição plena do seu titular.

Diante disso, é notório constatar-se que o âmbito de aplicação dos bons costumes como cláusula de limitação da relevância do consentimento do lesado está a se restringir cada vez mais, o que se deve, por certo, às crescentes pluralidades social e cultural hoje vivenciadas, as quais vêm a dificultar, em especial nos temas afetos a relações familiares $e$ 
práticas sexuais, a demarcaçẫo do que é contrário ou năo ao senso coletivo comum que lhe dá conteúdo.

Daí porque a forma mais adequada de regulação do tema talvez empregue referência apenas aos príncípios de ordem pública, dentre eles o da dignidade da pessoa humana, tendência esta acolhida pelo próprio artigo 81, n. 1, do Código Civil português quando trata da limitação voluntária dos direitos de personalidade, exemplo que bem pode ser seguido pelo legislador brasileiro ${ }^{43}$

\section{Formas Alternativas ao Consentimento Expresso}

Além do consentimento expresso, regra geral na hipótese de exclusão da ilicitude em apreço, podem-se verificar duas formas altemativas de aquiescência, a saber: o consentimento tácito e o consentimento presumido. Aquele é extraível do próprio sistema, porquanto, em teoria geral do direito civil, as declarações de vontade, em regra, podem-se dar de forma expressa ou tácita; este, não obstante à ausência de regulação legislativa na ordem jurídica brasileira, em Portugal, vem tratado no n. 3 do artigo 340 do Código Civil, segundo o qual "tem-se por consentida a lesão, quando esta se deu no interesse do lesado e de acordo com a sua vontade presumível".

5.1 o Consentimento tácito e a importância da assunção dos riscos

A figura do consentimento tácito como causa excludente da ilicitude surge sistematizada na doutrina de forma intimamente ligada às atividades que, por natureza, envolvam risco, com os quais anui o agente ao delas participar, mesmo que não o faça por meio de declaração expressa. 44 Daí porque

\footnotetext{
43 Esta é a posição defendida por Paulo Mota Finio (2004, p. 428), o qual menciona as dificuldades que advem do manuseilo do conceito de bons costumes "ern face da complexidade e da pluralidade de mundivivências das sociedades contemporâneas", refenindo uma preferencia pelo limite da ordem pública, não obstante em algurnas hipoteses restem por induzir conseqüencias iguais.

44 Jorge Ribeiro de Faria (1991, p. 450) faz referencia a "comportamentos sociais típicos" para deśignar o ato do sujeito consubstanciado na vontade de participar de
} 
o exemplo doutrinal mais freqüente da sua ocorrência (LEITÄO, 2000, p. 312; MARTINEZ, 2004, p. 108; VARELA, 1998, p. 554) guarde relação com os danos advindos da prática de esportes perigosos, tais como o boxe, as artes marciais, o râguebi e, até mesmo, o futebol, as quais estariam justificadas pela excludente em exame. ${ }^{45}$

Nestes casos, segundo a construção desenvolvida, a aderência do agente à prática dessas atividades, sabendo dos riscos que elas envolvem, autorizaria o ordenamento jurídico a considerá-la como consentimento tácito relativamente a eventuais danos que pudesse vir a sofrer, excluindo-se, pois, a sua ilicitude: ${ }^{46}$

E esta possibilidade decorre do fato de que, como ensina José de Oliveira Ascensão (2003, p. 48), "as manifestações negociais podem fazer-se por meros comportamentos", os quais podem ser considerados como declaraçóes em sentido amplo. Por isso é que, ainda segundo o autor, para a identificação deste fenômeno, ao invés da expressão declaraçâo tácita, seria preferivel a denominação "comportamento concludente" 47 .

O direito positivo não raro, lança mão da expressão "declaração tácita", como o faz, v.g., o artigo 217 do Código Civil

determinada atividade, mesmo gue perigosa, donde se pode extrair seu consenti mento tácito em relação aos danos eventualmente verificados.

${ }^{45}$ Da mesma forma, na doutrina de Dieter Medicus (1995a; p. 733), é possivel encontrar exemplo de consentimento tacito na hipótese daquele que aceita carona de condutor manifestamente desabilitado a conduzir. Na jurisprudência brasileira, é possível identificar caso envolvendo paciente que aceita submeter-se a tratamento experimental com determinado medicamento e, em decorrência, termina por sofrer alguma seqüela em rạão disso. Neste sentido: BRASIL. Tribunal de Justiça do Estado do Rio Grande do Sul. Apelaça Civel n. 70020090346. 9* Camara Cvel. Rel. Des. Odone Sanguiné. Julgado em: 26 set. 2007. Disponivel em: <http:/ www.ij:rs.gov,br>. Acesso em: 18 dez. 2007.

to Consoante assinala Luis Manuel Teles de Menezes Leitão (2000, p. 312), o consentimento tácito será, por isso, aquele que "resuite de um comportamento concludente do lesado", o qual "envolve uma aceitação tácita e recíproca dos riscos de acidente". ${ }^{4}$ Esta tambem é a posição de Luis Manuel Teles de Menezes Leitâo (2000, p. 312). Nào há, contudo, consenso em doutrina, havendo quem sustente a diferença entre comportamento condudente e declaraçăo tácita (PINTO, 1995. pp. 25 e ss). 
português ${ }^{48}$ pelo que, por decorrência, a denominaçāo consentimento tácito acaba sendo empregada, podendo, por lógica, ser associado às hipóteses em que se deduza dos fatos que, com toda a probabilidade, o revelem. ${ }^{49}$

Aqui, é oportuno que se distinga manifestação tácita de silêncio, já que, ao contrário daquela, neste não há qualquer externalização de vontade (ASCENSÃO 2003, p. 51 ); vale, contudo, como declaração negocial quando este valor decorra da lei, dos usos ou da vontade das partes, nos exatos termos dos artigos 218 e 111 dos Códigos Civis português e brasileiro.

Assim, em razão de tais pressupostos teóricos, é lícito afirmar que haverá, tanto no ordenamento português como no brasileiro, nestes casos, quando o comportamento do agente induza a exteriorização da sua aquiescência, efetivas formação e manifestação de vontade e não presunção acerca do consentimento (COSTA. 1991, 502). A diferença reside no fato de que a exterionização dessa concordância não se dá de forma expressa, mas tácita, razão pela qual, segundo sustenta

\footnotetext{
4s O Código Civil brasileiro, não obstante deixe de empregar em seu lexto a locuçăo "declaraçăo tácita", traz diversos dispositivơs que com ela guardam relaçâo. São exemplos disso os seus artigos $191,474,659,774 € 1.805$, o primeiro deles, inclusive, fazendo referência à renúncia tácita da prescriçăo, definindo-a como aquela que "se presume de fatos do interessado, incompativeis com a prescrição"; traz, assim, acepção bastante prôxima daquela encontrada para designar declaração tácita no Código Civil portugiees, comungando, ambos, pois, de mesmo conteúdo.

49 Neste particular, a jurisprudência portuguesa ja reconheceu que, para fins de exclusão da ilicitude, pode o consentimento ser "expresso por qualquer meío que traduza uma vontade séria, livre e esclarecida do titular do interesse juridicamente protegido", sendo que "nada permite concluir que tal expressäo não possa configurarse atravês de uma anuência tácita inequivoca, como é princípio geral de direito". (PORTUGAL. Tribunal da Relação de Lisboa. Recurso n. 0000592. Rel Des. Sousa Nogueira. Julgado em: 23 abr 1996. Disponivel em: < http://wwwdgsi.pt>. Acesso em: 17 fev. 2008). Tanto que já foi reconhecido, mesmo que para efeitos criminais, a justificação das lesões decorrentes de prática esportiva (futebol), uma vez que tacitamente consentida por aquele que dela participa. Cfr. PORTUGAL. Tribunal da Relação de Coimbra. Recurso n. 39/00. Rel. Des. João Trindade. Julgado em: 16 mar. 2000. Disponível em: <hitp:/wwwdgsi.pt>. Acesso em: 12 ago. 2008. Da mesma forma, a jurisprudência brasileira, ao reconhecer o consentimento tácito dos pais justificadores das lesóes sofridas pelo fitho que iniciou atividade como jogador de futebol nas categorias de base de determinado clube $e$, no seu desempenho, veio
}

Cademos do PPG em Direito UFRGS, Porto Alegre, v. 6, n. 7 e 8, p. 51-100, 2007 . 
parte da doutrina (BRIZ, 1962, p. 84), deverá ser interpretada restritivamente, incluindo apenas os danos estritamente presumiveis, situados dentro da margem de normalidade daquela atividade. ${ }^{50}$

Daí porque, no que toca às práticas esportivas que envolvam risco, é requisito à justificação que as lesōes não decorram de conduta dolosa de quem as pratica, bem como que, na sua produção, não concorram condutas contrárias às regras do jogo (COSTA, 1991, p. 502). O fundamento desta posição, o qual se mostra acertado, é que, nestas hipóteses, a lesão extrapolaria os limites do consentimento decorrente da assunção dos riscos da atividade, porquanto estranhas à sua prả́tica normal, nâo sendo dado ao participante, quando da aderência ao esporte, concordar que outros poderiam obrar com dolo na lesão ou que os seus regulamentos fossem desrespeitados.

Além disso, é forçoso concluir que os contornos do consentimento tácito deverão ser marcados pelo grau de conhecimento que o lesado tem dos riscos. Isto é, como já dito em momento anterior, a fim de que possa validamente formar e manifestar vontade, tal qual ocorre em relação ao consentimento expresso, mas, aqui, com maior relevo, o

\footnotetext{
a romper os ligamentos do joelho direíto em campo, afastando, portanto 0 dever de indenizar. $\mathbf{E}$ isso porque "na prática desportiva do fulebol, por sua própria natureza, 0 atleta é suscetivel a sofren chutes, golpes e choques de parte de atletas do clube adversáro que, muitas vezes, resultam em lesôtes, inclusive graves" (BRASIL. Tibunal de Justiça do Estado do Rio Grande do Sul Apelaçâo Civel n. $70011788148.9^{a}$ Câmara Civel. Rel. Des. Odone Sanguiné Julgado em: 24 ago. 2005. Disponivel em: <htp:/www.tis.govbr>. Acesso em: 18 dez 2007).

50 Nesta linha, entendendo que o consentimento tácito legitima apenas os danos normalmente decorrentes de dada atividade, asseverou o Supremo. Tribunal de Justiça portugués que em termos de vida real, é absurdo dizer-se que consentiu na lesão a pessoa que, ao ir comprar leite, é mordida por um cão 'pastor alemão', que guardava ó gado do dono" (PORTUGAL Súpremo Tribunal de Justiça Recurso de Revista n 085716. Rel. Cons. Cardona Ferreira. Julgado em: 20 jan 1994. Disponivel em: <http:/wwwdgsipt> Acesso em: 17 fev. 2008), afastando, com isso, a justificação das lesćes sofridas pela viüma. Tal é assim porque, como destacado no própno precedente, năo era razoável ao ofendido pressupor que ao dirigir-se àquele local, poderia ser mordido pelos cắes que guardava o rebanho, tendo, com isso, assumido 0 risco em relação à ocorrência destas lesões.
} 
lesado deve ter acesso a todas as circunstâncias que envolvern uma determinada prática que, em tese, venha a ser exposto, recebendo as oportunas informações a respeito, a firm de que dela decida participar com liberdade. ${ }^{5 .}$

Até porque a ausência ou insuficiência de informação podem inquinar o ato de vício de consentimento, pois a sua formação fundar-se-ia em premissa equivocada. Por essa razão, serão aplicáveis a respeito as disposiçōes acerca do erro na formação volitiva que, assim como a ignorância, conduz à uma falsa representação da realidade (ASCENSĀO, 2003 . p. 135), permitindo a manifestaçâo de um consentimento verdadeiramente nấo desejado, já que correspondente a situação fática diversa daquela em que se daria. ${ }^{52}$

Sobre esta temática, é oportuno que se refira o caso das ações indenizatórias manejadas por furnantes que restaram com a saúde comprometida pelo consumo de tabaco. Abstraindo-se qualquer ponderação acerca da irrenunciabilidade dos direitos de personalidade - no caso, vida e saúde -, o

\footnotetext{
51 Sobre a relevância dos deveres de informaçầ, notadamente quando o consentmento envolva a assunção de riscos, oportuno referir decisáo do Supremo Tribunal Administrativo português, o qual assentou que "os médicos dos estabelecimentos públicos de saúde têm o dever de prestar aos pacientes informaçốes adequadas sobre a sua situação, as alternativas possìveis ao tratamento e a evolução provável do seu estado, em ordem a permitir-ihes uma opção esclarecida entre receber ou recusar os cuidados de saúdo propostos" (PORTUGAL, Supremo Tribunal Administrativo. Recurso Jurísdicional n. 042434. Rel. Cons. Vítor Gomes Julgado em: 09 mar. 2000 Disponivel em: <http/ www dgst.pts. Acesso em is fev, 2008). A dificuldade, contudo, reside na amplitude do termo "informaçós adequadas", dada a extrema tecnicidade que envolve a ciência médica, bem assim todas aquelas que, da mesma forma, näo obstante encerrem riscos, pressuponham conhecimentos específicos para a compreensâo da informação. Exatamente por isso é que, na mesma linha da decisão anies referida, mas com conteudo um tanto quanto mais restritivo, entendeu a jurisprudência brasileira que "informar o paciente do tratamento não quer dizer explicar todos os detalhes particulares que estăo implicitamente conexos ou vinculados com o tratamento realizado segundo as lex artis ou que são inerentes à sua execucăo* (BRASIl Tribunal de Justiça do Estado do Río Grande do Sul. Apelação Cível n. 70009865544. 9 a Câmara Civel Rel. Des: Luis Augusto Coelho Braga. Julgado em: 31 ago, 2005. Disponivel em: khtp//wwwtj rs govbr>. Acesso em: 18 dez. 2007), mas somente aqueles que forem necessários e suficientes à sua leiga compreensâ dos acontếcimentos:

52 Ainda segundo José de Oliveira Ascensäo $(2003, \mathrm{p} .136)$, hă que se diferenciar o erro na formação da vontade do erro na sua declaraçăo. Enquanto naquele o erro
} 
que poderia, de antemão, afastar a incidência da causa de justificação em estudo, o ponto central da contenda envolvendo companhias fumageiras e usuários reside, justamente, no fato de saber se aquelas se desincumbiram do seu dever de informar estes acerca dos riscos do consumo do tabaco, possibilitando, assim, uma real assunção tácita dos riscos, o que implicaria exclusão da ilicitude.

Isso porque, para fins de justificar os danos advindos do fumo, alegam as empresas produtoras que os maleficios advindos do cigarro sâo de conhecimento geral, não havendo, pois, dever de informar acerca daquilo cujo conhecimento é amplo e irrestrito. A este argumento são contrapostos aqueles manejados pelos consumidores no sentido de que, nas décadas de 40 e 50 do século XX, quando os hoje demandantes iniciaram o hábito de fumar, não só nấo se divulgaram informações acerca dos riscos do consumo, como, ainda, a partir de intensa publicidade, construiu-se uma glamourizaçâo em torno do ato de fumar, fazendo com que os consumidores, após já dependentes do produto, quando, já na década de 80 daquele século, iniciaram as campanhas governamentais de esclarecimento e informação, não mais conseguissem abandonar o vício.

No Brasil,${ }^{53}$ os Tribunais, nâo obstante a avaliação tenha de ser feita caso a caso, têm reconhecido, em algumas hipóteses, a responsabilidade das indústrias fumageiras sob a alegação de que não haveria como se falar em consentimento válido - excludente da ilicitude - quando as fornecedoras deixaram de informar os consumidores sobre os riscos do cigarro, ainda mais porque já naquela época dispunham

fol responsável por uma formaçằo volitiva equivocada neste, o agente exprime defeituosamente sua intencăo, ou seja, "[a] intenção, af formou-se bem. 0 vício está apenas na externalização. Näo obstante serem diversas, estaräo sujeitas a regime análogo, tomando o consentimento dado irrelevante para fins de exclusaà da ilicitude.

53 Não se tem noticia de demanda semelhante em Portugal. A respeito da evoluçäo da jurisprudência em outros paises, nomeadamente na França nos Estados Unidos e na Alemanha, ver obra especifica de autoria de Cláudia Lima Marques (2005, p. 75 e ss). 
dessas informações e se omitiram em as repassar, não sendo elas, naquele período, de conhecimento amplo e geral, como se pretendeu fazer crer.

Assim, resta assente que, com efeito, para fins de que o consentimento seja validamente prestado pelo agente ao aderir a determinada atividade que envolva riscos, necessário que tenha as informaçôes a respeito destes, podendo bem avaliar a conveniência e oportunidade de praticá-la e, diante disso, arcar com estes riscos.

Em resumo, é usual exigir-se, para fins de justificação da conduta pela aquiescência tácita do ofendido, que os danos dela decorrentes estejam previstos dentro da normalidade daquela atividade determinada, năo se admitindo que se aleguem riscos imprevisiveis ou que estavam fora da margem de suposição do autor do consentimento, com base nas informaçöes de que ele dispunha a respeito.

Como sé pôde até aqui delinear, a excludente do consentimento tácito vem, em grande parte, associada à assunção dos riscos de determinada prática, o que justificou, desta forma, a pretensão de dar-lhe autonomia jurídica. Esta tendência tem sido verificada, especialmente, em parte das doutrinas anglo-americana (assumption of risk), francesa (acceptatios des risques) e alemã (Handeln auf eigene Gefahr) (PROENÇA, 1997, p. 616), não obstante, inclusive nestes sistemas jurídicos, mesmo a par de uma relativa autonomia da figura da "assun çâo do risco", continue a se verificar a sua confluência com o princípio volenti non fit iniuria justificador da exclusâo da ilicitude pelo consentimento tácito. ${ }^{54}$

Ocorre que esta pretensa autonomia, criadora de uma figura "nebulosa e heterogênea" (PROENÇA, 1997, p. 615),

\footnotetext{
54 Josê Carlos Brandão Proença (1997, p. 616) destaca, inclusive, que a orientaçào dorninante na doutrina estrangeira, após uma certa contenda, tem apontado para a recusa de uma posição autónoma da figura da assunçāo dos riscos. Ainda, consoante destaca o mesmo autor $(1997, \mathrm{p}, 620)$, no cenáno jurídico português, o qual, en conjunto com o ordenamento brasileiro, é o objeto precipuo deste estudo, "[o] escasso tratamento que a nossa doutrina dedicou (e dedica) à "assunçao do risco" não fornece subsídios bastantes para que se possa descortinar uma tomada de posiço sebre a vexata quacstio da autonomia da figura".
}

Cademos do PFG em Direito UFRGS, Forto Alegre, v. 6, n. 7 e 8, p. 51-100, 2007. 
tem chamado a atenção para pontos que, ao que parece, passaram despercebidos da construção original formulada pela doutrina clássica, nã́o obstante fossem identificáveis na tradição romana que os justificou. Isso porque, em especial no que toca às práticas desportivas e aos riscos a elas associados, corriqueiramente relacionados com o consentimento tácito do lesado, não obstante se verifique a suposta "atribuição de um poder de lesão". (PROENÇA, 1997, p. 614), pode-se constatar uma concomitante crença do sujeito de que esta não se verificará. Por isso é que, para muitos, pareceria irreal falar em consentimento tácito justificador de danos que, em verdade, o sujeito acredita que não se iriam concretizar (FRADA, 2006, p. 77).

Segundo Manuel Cameiro da Frada (2006, p. 77), a solução para a controvérsia está na adoção da teoria da direção da vontade, ${ }^{55}$ largamente aceita pelo Direito Penal, nos termos da qual "a declaração não releva, pode até nem existír, importando, isso sim, a direcção da vontade de quem consente. Com isso, o consentimento do lesado amplia-se na direcção de outras figuras", restando por abarcá-las, dentre elas, a assunção de riscos.

Desta feita, pelo que parece, ao se expor ao risco inerente a determinada atividade, o lesado direciona sua vontade e assente na eventual ocorrência de danos a ela intrínsecos, os quais restam justificados por este comportamento, que deve ser interpretado como consentimento tácito (COSTA, 1991, p. 502), permanecendo as hipóteses em apreço abrangidas pela figura ora estudada, sem justificativa, ao menos a partir da construção teórica hoje existente a respeito, para a construçăo de uma figura autônoma.

Do esboço apresentado é possível extrair que a falta de regulamentação legislativa do tema no ordenamento brasileiro não representa entrave para que a figura seja reconhecida

\footnotetext{
${ }_{55}$ Para aprofundamentos sobre a teoria da direção da vontade e a sua operatividade em tema de exclusão da ilićtude pelo consentimento, ver os ensinamentos de Claus Foxin (1997, p. 534).
} 
e aplicada, tal qual ocorre na realidade jurídica portuguesa, mesmo que com contornos oscilantes. Nâo obstante não se possa encontrar a mesma preocupação doutrinária com que o tema vem sendo tratado em Portugal, o fato de reconhecerse, no Brasil, o consentimento do lesado como causa supralegal de justificaçắo aliado à possibilidade genérica prevista no sistema de que as manifestações negociais possam ser expressas ou tácitas ${ }^{5}$ aponta para uma uniformidade no tratamento das questóes no âmbito comparativo proposto.

5.2 Presunção de consentimento: a atuação em interesse alheio

A mesma uniformidade aparente verificada nos ordenamentos português e brasileiro no que toca ao tratamento do consentimento tácito, porém, parece não poder ser afirmada em matéria de consentimento presumido. ${ }^{57}$ Isso porque a inexistência de regra codificada no Brasil, ao contrário do que ocorre no Código Civil portuguếs, induz, não raro, a um tratamento jurídico díspar acerca de questões faticamente idênticas, o que se pode imputar, por certo, a essa ausência de regulação, o que bem demonstra não ser ela tão supérflua como sustentado por parte da doutrina brasileira (TOLEDO, 1984, p. 128).

Como já antes referido, o artigo 340, n. 3, do Código Vaz Serra estatui que "[t]em-se por consentida a lesão, quando esta se deu no interesse do lesado e de acordo com a sua

\footnotetext{
56 Isso é o que se infere do artigo I07 do Código Civil de 2002, segundo o qual "[a] validade da declaraçăo de vontade năo dependerá de forma especial, senäo quardo a lei expressamente a exigir".

${ }^{57}$ Segundo Délio Magalhäes (1968, p. 112), o consentimento presumido foi primeiro tratado por Ernst Zitelmann; na seqüềncia, dedicou-lhe estudo monográfico Arndt, intitulado Die mutmassliche Einuilligung als Rechifertigungsgruind Strafr., sendo, entretanto que, segundo aquele autor, apenas com Edmund Mezger foi melhor desenvol vido, quando, então, restou associado à "gestão de negócios sem encargo". Em sentido contrário, Adriano Vaz Serra (1959, p. 108) identifica já na obra Auschuluss der Widerrechtlichkeit, de Emest Zitelmann, publicada em Archiv f. d. c. Praxis, n. 99, p. 104 e ss, a até hoje aceita associação entre o consentimento presumido e a "gestão útil de negócios". A propósito, com extensa indicaçäo bibliografia em língua alemä sobre o tema, ver as liçöes de Hans-Heinnich Jescheck e Thomas Weigend (2002. p. 413).
} 
vontade presumivel". Ou seja, constitui uma ficção de consentimento (MARTINEZ, 2004, p. 108) que a lei extrai do fato de a intervenção na seara alheia ter-se dado no interesse do próprio titular ao contrário do que ocorre no consentimento tácito, em que a anuência prévia do ofendido existe, mas se exterioriza por meios outros que não uma declaração expressa. Por esta razão, tem sido tratado pela doutrina como uma causa de justificação sui generis (JESCHECK; WEIGEND, 2002, p. 413).

Daí porque estar a figura freqüentemente associada aos casos em que o titular dos interesses em causa não se encontra em condiçōes de prestar seu consentimento, sem prejuízo de as circunstâncias concretas autorizarem presumir que, caso fosse transposta dita impossibilidade, o lesado, por certo, anuiria com a intervenção na sua seara juridicamente protegida.

Os exemplos mais comuns verificam-se, além dos casos de cirurgias de urgência realizadas sem a prévia aquiescência do paciente, os quais adiante melhor serão tratados, na hipótese daquele que arromba a porta da residência de um vizinho que se encontra em viagem para conter vazamento de água o qual, por certo, destruiria a residência antes do seu retomo (os danos causados na porta restam justificados pelo consentimento presumido do proprietário) ou do agente que abre correspondência de um amigo para fins de adotar providências imprescindiveis ao seu interesse, dada a sua impossibilidade momentânea de assim o proceder (MEZGER, 1946, p. 414). Ainda, é freqüente falar-se na hipótese do ato de correção praticado em relação a menor que se encontra sob os cuidados de pessoa distinta daquela que detém o poder parental (BRIZ, 1962, p. 84), bem como no caso de quem ofende corporalmente o náufrago que se encontra em estado de desespero para, com isso, poder salvá-lo da morte por afogamento (MEZGER, 1946, p. 414).

Diante disso, é possível afirmar, consoante o faz Edmund Mezger $(1946,414)$, que a antijuridicidade desaparece a partir do consentimento presumido, o qual pressupõe "um juízo de 
probabilidade objetivo do juiz que expressa que o suposto lesado, se possuísse um completo conhecimento da situação de fato, teria, do seu ponto de vista pessoal, consentido na ação".

O fundamento dessa figura, em decorrência destas condições fáticas, guarda intrínseca relação com a gestão de negócios sem mandato (BRIZ, 1962, p. 84, FARIA, 1991, p. 450) ou, pelo menos, com situação a ela análoga (SERRA, 1959, p. 108), pelo que os requisitos de ambas terão íntima identidade (VARELA, 1998, p. 553). Surgem, assim, dois pressupostos imprescindíveis a que a ingerência na esfera jurídica alheia, nestas hipóteses, reste justificada (JORGE, 1995, p. 278): um primeiro - utiliter coeptum -, relacionado com a intenção do agente em agir no interesse do titular do interesse em causa, e, um segundo, consubstanciado na atuação consoante sua vontade real ou presumivel. ${ }^{58}$

Neste aspecto, deve-se ter cuidado para que a formulação apresentada não induza em confusão entre vontade presumida do titular do interesse em causa e consentimento presumido. Isso porque a vontade do lesado pode ser efetivamente conhecida por parte daquele que atua acobertado pela excludente; tal, contudo, não faz com que se possa dizer que ele possui autorizaçấo para agir: a vontade é conhecida, mas o consentimento, em razão dessa vontade, é presumido. Noutros casos, porém, poderá a vontade ser presumível e, em decorrência desta presunção, também o consentimento ser implícito. Em suma, o consentimento sempre será presumido - se assim nấo for, a hipótese será de consentimento real -, sendo que a vontade poderá ser real ou presumida.

O importante é que essas presunções sejam pautadas por critérios objetivos (COSTA, 1991, p. 501), ou seja, que a partir de um "juízo do homem médio" possa-se valorar o caso

\footnotetext{
${ }^{58}$ Estes requisitos são aqueles estabelecidos pelos artigos 464 e 465 , alínea "a", ambos do Código Civil português. Nâo discrepa o regime da gestâo de negócios contido no artigo 861 do Código Civil brasileiro, de igual forma aplicável na delimitaça das hipóteses de consentimento presumido.
} 
concreto e concluir que, naquela situação, seria razoável presumir o consentimento de qualquer pessoa, diante dos interesses postos em causa e da ponderação entre as conseqüências da atuação e da abstenção.

Se o agente tem, todavia, conhecimento da vontade real do titular do bem jurídico, mesmo que esteja pautada por critério subjetivo, contrária àquela extraível do senso comum, ela - vontade real - prevalecerá. Isso é o que ocorre no caso de, na premência de lesão a determinado bem jurídico de pequeno valor, o agente, sabedor da grande estima e afeição que lhe nutre o dominus, sacrifica bem jurídico patrimonialmente mais valioso deste, salvaguardando o primeiro. Talvez, a partir de uma ponderação objetiva, diante da desproporção entre o valor econômico dos bens, pudesse crer que o consentimento náo existiria; diante, porém, do fato de conhecer a vontade real do proprietário, a presunção do consentimento resta autorizada.

A questão relacionada ao conhecimento da vontade real do agente e as conseqüências da sua contrariedade ao consentimento pautado por padrōes objetivos apresentará alguma controvérsia quanto versar sobre bens indisponiveis. ${ }^{59}$ Será imprescindivel, desta feita, levar novamente em conta as ponderaçōes já apresentadas quando se tratou da indisponibilidade dos interesses postos em causa, o que, por oportuno, adiante se fará.

Contudo, e daí a importância de que, desde logo, adentrese no tema, as situaçōes práticas relacionadas ao consentimento presumido justificador verificam-se, com maior freqüência, nas hipóteses de intervenções médicas de urgência, nas quais a vítima, não obstante careça de pronto atendimento

\footnotetext{
${ }^{50}$ Exemplo freqüente acerca do tema aponta para o caso daquele que agride alguém que se afoga com o fim exclusivo de salvar-the a vida e, depois, descobre que se ratava de um suicida; assim, mesmo que a posteriori venha-se a saber que a vontade do titular da proteçăo jurídica apontava em sentido contrário à atuação do agente, este permanecerá acobertado pela excludente em decorrếncia da natureza indisponivel da vida. Nestas hipóteses, "o consentimento presumido prevalecerá atê contra a vontade expressamente declarada" (MAGALHÂES, 1968, p. 114), isso em funçäo da indisponibilidade, pelo lesado, do interesse jurídico en causa.
} 
interventivo, não se encontra em condições de anuir com tal procedimento (LARENZ, 1959, p. 591).

Nestes casos, no ordenamento jurídico português, por força da regra explícita do artigo 340, n. 3, do Código Civil, o consentimento do lesado é presumido em decorrência da intervenção na sua esfera juridicamente protegida vir em seu benefício ou interesse, no caso, na manutenção da sua vida e saúde, justificando-se eventuais lesões que para tal fim maior sejam necessárias.

A situaçăo é passivel de maior controvérsia na ordem jurídica brasileira, em decorrência, como já asseverado, da ausência de regramento expresso. Tal, contudo, não impede que situações desta natureza sejam verificadas no mundo dos fatos e, desta feita, exijam respostas efetivas do sistema.

Daí decorrerá a necessidade de um maior esforço do interprete na tentativa de excluir a ilicitude do comportamento inicialmente contrário ao direito, justificando-o em razão da necessidade premente da intervenção e da impossibilidade da prévia anuência do interessado, quanto mais porque seu consentimento é presumível a partir de uma vontade também presumida sua (manter a própria vida).

Ocorre que a mencionada ausência de regulamentação do tema em preceito autônomo do Código Civil, tal qual existente no congênere português, tem conduzido a uma série de soluções díspares para casos idênticos, contribuindo para uma atecnia acerca da melhor solução jurídica para as hipóteses de intervenções médicas não expressamente consentidas.

A posição mais usualmente encontrada parece ser aquela que associa a intervenção urgente à ocorrência de um estado de necessidade justificador. Para parte da doutrina, seja civil (DIAS, 1950, p. 280), seja penal (PRADO, 2002, p. 276), no que segue acompanhada por parcela da jurisprudência, ${ }^{60}$ nestes casos, "[f]undamenta-se o estado de

* Neste sentido, "Apelaçäo civel Responsabilidade civil. [...] İntervençäo cirúrgica de urgência. Ablaçấo dó rim direito do autor. Solução emergencial, adotada no 
necessidade, porque a conduta do médico visa afastar perigo atual ou iminente a bem jurídico alheio (vida do paciente), cujo sacrifício, nas circunstância, não era razoável exigir-se" (PRADO, 2002, p. 276).

A compreensão e o exame da viabilidade de tal solução jurídica pressupõem o conhecimento de como a matéria relacionada ao estado de necessidade vem tratada na ordem jurídica brasileira. $\mathrm{O}$ artigo 188 , inciso II, do Código Civil, sem fazer referência expressa à excludente do estado de necessidade, refere que nấo constituem atos ilícitos "a deterioração ou destruição da coisa alheia, ou a lesão a pessoa, a fim de remover perigo iminente" ${ }^{61}$

Ora, pelo que se vê, o dispositivo de regência faz menção expressa à necessidade de que os interesses sacrificados sejam alheios - leia-se, aqui, alheio ao sujeito que age $e$ alheio ao sujeito que se beneficia do agir -, de modo que, na mesma linha do que vem sendo sustentado pela doutrina

decorrer do ato cirurgico, com o fito de preservar a vida do demandante, sob risco iminente. Consentimento prévio do autor e dos seus familiares que não se afigurava necessário, nesse contexto, em face do estado de necessidade e da siluação de perigo iminente [...]". (BRASIL. Tribunal de Justiça do Estado do Rio Grande do Sul. Apelação Civel n. 70005386727. $9^{\text {a }}$ Câmara Civel. Rel. Juiz Miguel Ângelo da Silva. Jülgado em: 23 mar. 2005. Disponível em: <hitp:/www.lj.rs.gov.br>. Acesso em 13 abr. 2008).

${ }^{61}$ Na ordem jurídica portuguesa, por força do artigo 339, n. 1, do Código Civil, tem-se que "[é] lícita a ação daquele que destruir ou danificar coisa alheia com o fim de remover perigo actual de um dano manifestamente superior, quet do agente, quer de terceiro". Não obstante a regra nada diga expressamente a respeito, a doutrina tem entendido que "[o] estado de necessidade số se coloca se o sacrificio de bens patrimoniais for realizado no âmbito de uma esfera jurdica distinta daquela ameaçada por um perigo manifestamente superior", o que excluira a possibilidade de coincidência entre a titularidade dos bens atingidos e daqueles que venham a ser sacrificados, tal qual ocorre nos casos de cirurgias de emergência desprovidas de consentimento prévio (LEITÂO, 2000, p. 276). Isto se extrai da conjugação das expressóes "coisa alheia" e "quer do agente, quer de terceiro", o que autoriza a interpretar que aquela não pode dizer respeito a estes. Com base no mesmo racioónio, João de Matos Antunes Varela (1998, p. 550) sustenta que "[s]e, para salvar interesse alheio, agente sacrifica um interesse proprio [...], nâ é o estado de necessidade, mas a gestäo de negócios ou a responsabilidade civil, que the facultará a possibilidade de indemnizaça dos danos que sofrer". Dai porque se conclui que a "coisa alheía" sacrificada näo possa pertencer àquele que age acobertado pela excludente ou àquele que se beneficia da atuação justificada. 
portuguesa, nầo é da melhor técnica interpretativa fazer coincidir na mesma pessoa a titularidade do bem jurídico atingido pelo ato acobertado pelo estado de necessidade com a titularidade dos interesses salvaguardados pelo agir tornado lícito pela excludente. ${ }^{62}$

Diante dessas ponderações, mostra-se inadequada a justificação dos atos cirúrgicos de urgência realizados sem o prévio consentimento do paciente com base no estado de necessidade, pois, para tanto, será necessário fazer coincidir na mesma pessoa a condiçấo de lesado, de titular do bem atingido e de titular dos interesses salvaguardados pela ação justificada, o que não se mostra adequado.

Ainda no que toca ao tratamento dado pelo direito brasileiro ao caso das cirurgias não expressamente consentidas, a questäo, do ponto de vista da dogmática jurídica, fica ainda mais controversa quando se atenta à regra contida no artigo 46 do Código de Ética Médica (Resolução n. 1.246/88, do Conselho Federal de Medicina), segundo a qual é vedado ao médico "efetuar qualquer procedimento médico sem o esclarecimento e o consentimento prévio do paciente ou de seu responsável legal, salvo em iminente risco de vida". ${ }^{63}$ Isso porque, ao nāo fazer referência a qualquer das figuras especiais de exclusão da ilicitude, não obstante esteja a tratar do consentimento presumido, dá a entender que o profissional

\footnotetext{
62: Ao que se tem conhecimento, a doutrina civilista brasileira silencia totalmente acerca destas hipóteses, nada referindo sobre a necessidade de que os interesses sacrificados sejam alheios ao agente e ao beneficírio do estado de necessidade. Talvez tal se possa inferir das liçôes de Sergio Cavalierí Filho (2006, p. 42), em especial quando afirma, sobre o estado de necessidade, que "[q]uando o direito de alguém está em conflito com o direito de outrem, a lei permite que o conflito seja resolvido pelo desaparecimento ou cessação transitóra do direito menos valioso do ponto de vista ético e humano". Assim, ter-se-ia que a figura em exame pressupōe conflito de interesses de títularidades diversas, tal qual sustentado por parte da doutrina portuguesa (LETA Â, 2000, p. 276).

6* Não é diversa a regra do artigo 146 , parágrafo $2^{\circ}$, inciso 1 , do Código Penal brasileiro, o qual, quando trata do crime de constrangimento ilegal, exclui o sêu âmbito de incidência a hipótese de "intervençấo médica ou cirúrgica, sem o consen timento do paciente ou de seu representante legal, se justificada por iminente perigo de vida".
} 
da saúde, nestas hipóteses, age no cumprimento de dever legal de zelar pela vida do paciente, o que, inclusive, negaria relevância jurídica à aquiescência do lesado. ${ }^{64}$

Também não parece ser esta a melhor interpretação, porquanto ao tratar a questăo dentro da disciplina da excludente geral do exercício regular de direito ou do cumprimento de dever, deixa-se-lhe de impor os limites verificados quando tratada no âmbito do consentimento presumido do lesado que a atuação ocorra no interesse do titular do bem jurídico em causa e de acordo com a sua vontade real ou presumivel -, os quais decorrem da aplicaçăo analógica do regime da gestão de negócios. A margem de atuação resta por apre. sentar-se demasiado lata, desconsiderando os interesses daquele a quem a ordem jurídica concedeu a disponibilidade - mesmo que parcial ou restrita - sobre os interesses protegidos, uma vez que, em prevalecendo essa interpretação, o objetivo primordial do agir não será a satisfação do interesse alheio, como na gestão de negócios, mas o cumprimento do dever daquele que age.

A única conveniência dessa interpretação - justificação pelo cumprimento de dever - reside nas hipóteses em que aquele que age tem conhecimento da vontade expressa do titular do interesse, a qual aponta para o dissenso quanto ao ato médico necessário, não obstante, à luz de preceitos objetivos, a melhor opção apontasse para a atuação consentida.

\footnotetext{
ta Esta posiça ja fol acolhida por parte da jurisprudencia brasileira ao assentar que "o profissional da saúde tem o dever de, havendo iminente perigo de vida empreender todas as diligências necessarias ao tratamento da paciente, independentemente de consentimento dela ou de seus familiares", consentimento este que, no caso, em decorrência de convicçós religiosas, aponteva em sentido contráno à intervençâo médica a ser realizada. O Tribunal, em razâo disso, entendeu que falecia interesse processual ao nosocómio em buscar autorização judicial para agir em sentido contrărio à convíç̧ăo religiosa do paciente, poís, nessa hipotese, mesmo à vista do dissenso, estaria o médico agindo em cumprimento a dever legal. Neste sentido: BRASIl. Tribunal de Justiça do Estado do Rio Grande do Sul. Apelação Cível n. $70020868162.5^{3}$ Câmara Civel. Rel Des. Umberto Guaspari Sudbrack Julgado em: 22 ago. 2007. Disponivel em: <http:/wrw.t.rs.gov.br>. Acesso em: 18 dez. 2007
} 
Esta hipótese coincide com os já referidos casos em que o paciente encontra-se em situação de urgência, carecendo de pronta intervenção; ocorre que, não obstante nắo se possa manifestar de modo expresso, sua vontade é conhecida e indica no sentido da não-realização do procedimento - seja cirúrgico, seja de transfusão de sangue - com freqüência por razóes religiosas.

A solução, aqui, todavia, não reside no regramento que trata do consentimento presumido, o qual, como dito, deve ceder diante da vontade real do sujeito, mesmo quando pautada por critérios subjetivos, náo obstante eventual vontade presumível a partir de preceito objetivo indicasse em sentido contrário. O controvérsia assentar-se-á na disponibilidade dos direitos envolvidos, nomeadamente à vista do princípio da dignidade da pessoa humana e do seu objetivo último de proteger o sujeito dele próprio, não sendo necessário que, para fins de negar relevấncia à vontade do lesado, tenha-se de recorrer à figura de justificação do exercício de dever.

Em sendo considerado disponível o direito, a vontade real prevalece, não havendo consentimento justificador; em prevalecendo, contudo, a tese da indisponibilidade, que, aliás, parece ser majoritária na jurisprudência ${ }^{65}$ mesmo não

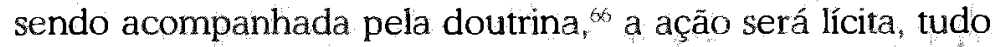
se resolvendo dentro da figura do consentimento do lesado, sem necessidade de recurso a outros institutos.

\footnotetext{
${ }^{65}$ Exemplificativamente: BRASIL. Tribunal Regional Federal da $4^{\mathrm{a}}$ Regiâo Apela-

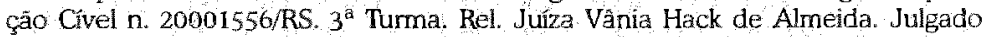
em: 24 out 2006. Dispónivel em: <http//wwwjusticafederal.govbr> Acesso em: 04 mar. 2008. BRASIL. Tribunal de Justiça do Estado de São Paulo. Apelação n. 132720-4/9. $5^{a}$ Camara de Direito Privado. Rel Des. Boris Kauffmann. Julgado em: 26 jun. 2003. Disponivel em <http//www.t.sp.gov.br>, Acesso em: 08 abr. 2008; BRASIL. Tribunal de Justiça do Estado do Rio Grande do Sul. Apelaçáo Cível $n$. $70020868162.5^{\text {a }}$ Câmara Cível. Rel. Des. Umberto Guaspari Sudbrack. Jülgado em: 22 ago. 2007. Disponfvel ems <http//wwwtj.rs govbr>. Acesso em: 08 abr. 2008, dentre tantos outros.

to Sobre o tema, ver, dentre ouras, obra especfica de Celso Ribeiro Bastos (2001, p. 495 e ss).
} 
Diante do panorama apresentado, é notória a carência de regulamentação, na ordem jurídica brasileira, da figura do consentimento do lesado como causa excludente da ilicitude, notadamente na hipótese em que este consentimento não pode ser previamente colhido e a atuação se dá em beneficio do próprio interessado (presumido), a exemplo do que fez o artigo 340 do Código Civil português possibilitando, em decorrência disso, a sistematizaçăo da matéria e a solução harmônica das hipóteses que exijam a intervenção do direito a fim de serem resolvidas.

\section{Conclusão}

Encerrada a exposição, algumas ponderações merecem ser feitas no que toca ao tema proposto, em especial a partir da análise apresentada sobre a forma como se apresenta a relevância do consentimento do lesado em tema de responsabilidade civil nas ordens jurídicas em exame.

É notória a superioridade da regulação legislativa existente em Portugal em tema de responsabilidade civil. A legislação brasileira, mesmo sendo recente, apresenta uma série de falhas, designadamente no que toca ao conceito de ilicitude e às suas causas de exclusão (artigos 186 e 188 do Código Civil), exigindo atenção do interprete a fim de bem aplicá-las, sendo o exemplo português de grande ajuda.

O mesmo ocorre no que diz pertine à regulação do consentimento do lesado, mostrando-se equivocado o então caráter supérfluo que motivou deixar de introduzi-lo como causa de justificação no Código Penal brasileiro. Assim, também no direito civil em que, sem qualquer razão aparente, o tema vem sendo negligenciado, abrindo margem, diante da onissâo legislativa verificada, para inúmeras confusôes quando da sua aplicação, dada a completa desorientação dos operadores do direito na sua concretização.

De igual modo, o tema não vem merecendo a atenção necessária por parte da doutrina, o que ocorre, mesmo que 
em menor grau, inclusive em Portugal. Isso porque o consentimento do lesado tem recebido, na maioria das vezes, restrito tratamento, diluído dentro do livro do direito das obrigações, quando do exame das hipóteses de exclusão do dever de indenizar, sem maiores ponderações a respeito, limitando-se, a maior parte dos autores, a fazer-lhe referência, com reprodução daquilo que expressamente consta já na lei civil.

É consenso, contudo, que, quando prestado, excluirá a ilicitude da conduta, afastando o surgimento do dever de indenizar, năo como uma renúncia ao direito de crédito, mas como uma disposição do diritto primario em si.

As maiores controvérsias, seja em Portugal, seja no Brasil, dizem respeito aos limites da sua relevância, nomeadamente quando digam respeito a direitos indisponíveis, dentre eles os de personalidade, isto em decorrência das controvérsias existentes acerca do alcance desta (in)disponibilidade.

De igual modo, o regime jurídico altemativo ao consentimento expresso, consubstanciado nas formas tácita e presumida de aquiescência, é de aplicação prática bastante importante, sendo oportuno o seu adequado tratamento.

Como referido, a figura do consentimento tácito é de estruturaçăo relativamente fácil a partir das regras gerais da teoria geral do direito civil, em ambas as ordens jurídicas analisadas, o que năo pode ser de igual modo dito no que toca ao consentimento presumido neste aspecto, a regulação portuguesa é exemplar (artigo 340, n. 3, do Código Vaz Serra), sendo exemplo a ser seguido pelo legislador brasileiro, solvendo o impasse hoje existente na doutrina e na jurisprudência deste país acerca da resoluçâo dos casos práticos a ele correspondentes.

Assim é que se mostraria adequada uma revisão do artigo 188 do Código Civil de 2002, no sentido de nele incluir o consentimento do lesado como causa de exclusão da ilicitude, năo só na sua modalidade expressa, mas também tácita e presumida, tomando-se, para tanto, como exemplo, o reconhecidamente eficiente modelo do artigo 340 do Código Civil português de 1966. 


\section{Referências}

AMARAL, Francisco. Direito Civil: Introdução. Jed. Rio de Janeiro: Renovar, 2000 .

ASCENSÄO, José de Oliveira, Direito Civil - Teoria Geral. 2ed. Coimbra: Coimbra, 2003, vol. Il.

BASTOS, Celso Ribeiro. Direito de recusa de pacientes submetidos a tratamento terapêtico às transfusoes de sangue, por razôes cientificas e convicçôes religiosas. Revista dos Tribunais, Sao Paulo, a. $90, n .787$, p. 493-507, mai. 2001.

BELEZA, Teresa Pizarro. Direito Penal, Lisboa: AAFDL, 1980, vol 2.

BRIZ, Jaime Santos. Derecho de Daños. Madrid: Revista de Derecho Privado, 1962.

BRUTAU, José Puig. Fundamentos de Derecho Civil. Enriquecimento injusto. Responsabilidad extracontractual. Derecho a la intimidad. Barcelona: Bosch, 1983, t. II, vol. III.

CAVALIERI FILHO, Sergio. Programa de Responsabilidade Civil. 6ed. Säo Paulo: Malheiros, 2006

CORDERO, António Menezes. Da Responsabilidade Givil dos Administra dores das Sociedades Comerciais. Lisboa: Lex, 1997.

Tratado de Direito Civil Português. 3ed. Coimbra: Almedina, 2007a, Parte Geral, t. I, reimp.

Tratado de Direito Civil Português. Coimbra: Almedina, 2007b, Par te Geral, t. IV, reimp.

Da Boa Fé no Direito Civil 3reimp. Coimbra: Almedina, $2007 \mathrm{c}$.

COSTA, Mário Júlio de Almeida. Direito das Obrigaçōes. 7ed. Coimbra: Almedina, 1998.

DE CUPIS, Adriano. Il Danno - Teoria general della responsabilità civile $3 e d$. Milano: Giuffrè, 1979.

DIAS, José de Aguiar. Da Responsabilidade Civil. 2ed. Rio de Janeiro: Forense, 1950 .

DÍEZ PICAZO, Luis Derecho de Daños. Madrid: Civitas, 2000, reimp. 
ENNECCERUS, Ludwig. Derecho de Obligaciones. Atual por Heinrich Lehmann. Trad. espanhola da 35ed. alemã por Blas Pérez Gonzalez e José Alguer. Barcelona: Bosch, $1935 \mathrm{a}$, vol. II.

- Derecho Civil (Parte General). Atual. por Hans Carl Nipperdey. Trad espanhola da 39ed. alemã por Blas Pérez Gonzales e José Alguier. Barcelona: Bosch, 1935b, vol. II.

ESTEVILL, Luis Pascual. Derecho de Daños 2ed. Barcelona: Bosch, 1995, t. I. FARIA, Jorge Ribeiro de Direito das Obrigaçōes Coimbra: Almedina, 1991, t. l. FERREIRA, Manuel Cavaleiro de. Liçôes de Direito Penal. Parte Geral A lei penal e a teoria do crime no Código Penal de 1982. 3ed. Lisboa: Verbo, 1988, t. I. FRADA, Manuel A. Cameiro da. Contrato e Deveres de Proteção. Coimbra: Coimbra, 1994.

. Direito Civil Responsabilidade Civil. O método do caso. Coimbra: Almedina, 2006.

FRAGOSO, Heleno Cláudio. Liçōes de Direito Penal. A nova parte geral. 4ed. Rio de Janeiro: Forense, 1994

GOMES, Orlando. Introdução ao Direito Civil. ged. Rio de Janeiro: Forense, 1987.

JESCHECK, Hams-Heinrich; WEIGEND, Thomas. Tratado de Derecho Penal: parte general. 5ed. Trad. espanhola de Miguel Olmedo Cardenete. Granada: Comares, 2002.

JORGE Femando Pessoa. Ensaio sobre os Pressupostos da Responsabilidade Civil. Coimbra: Almedina, 1995, reimp.

LARENZ, Karl. Derecho de Oligaciones. Trad. espanhola de Jaime Santos Briz. Madrid: Revista de Derecho Privado, 1959, t. II.

LEITÄO, Luis Manuel Teles de Menezes. Direito das Obrigações. Coimbra: Almedina, 2000, vol. I.

LIMA, Femando Andrade Pires de; VAREIA, Joāo de Matos Antunes. Código Civil Anotado. 3ed. Coimbra: Coimbra, 1982, vol. I.

LOURENÇO, Paula Meira. A função punitiva da responsabilidade civil, Coimbra: Coimbra, 2006.

MAGALHĀES, Délio. Causas de Exclusão do Crime. São Paulo: Saraiva, 1968. 
MÁRQUES, Cáudia Lima. Violação do dever de boa-fé de informar corretamente, atos negociais omissos afetando o direito/liberdade de escolha. (parécer). Revista dos Tribunais, São Paulo, v. 97, n. 835, pp. 75-133, mai. 2005.

MARTINEZ, Pedro Romano. Díreito das Obrigações - Apontamentos zed. Lisboa: AAFDL, 2004.

MARTINS-COSTA, Judith. Ação indenizatória - Dever de informar do fabricante sobre os riscos do tabagismo (parecer). Revista dos Tribunais, São Paulo, v. 92, n, 812, pp. 75-99, jun. 2003.

MEDICUS, Dieter. Tratado de las relaciones obligacionales. Trad. espanhola de Ángel Martínez Sarrión. Barcelona: Bosch, 1995, vol. I e II.

MEZGER, Edmund. Tratado de Derecho Penal. Trad, espanhola de Jose Arturo Rodriguez Muñoz. Madrid: Revista de Derecho Privado, 1946.

MONTEIRO, António Pinto. Cláusulas limitativas e de exclusão da responsabilidade civil Coimbra: Coimbra; 1985.

MONTEITO, Jorge Sinde. Estudos sobre a responsabilidade civil. Coimbra: Almedina, 1983.

PRADO, Luiz Regis. Curso de direito penal brasileiro. Parte especial. 2ed. São Paulo: Revista dos Tribunais, 2002, vol. 2.

PRATA, Ana. Cláusulas de Exclusão e Limitação da Responsabilidade Contratual. Coimbra: Almedina, 1985.

PROENÇA, José Carlos Brandão. A conduta do lesado como pressupostoe critério de imputação do dano extracontratual. Coimbra: Almedina, 1997.

PINTO, Carlos Alberto da Mota. Teoria Geral do Direito Civil Atual. António Pinto Monteiro e Paulo Mota Pinto. 4ed. Coimbra: Coimbra, 2005.

PINTO, Paulo Mota. Declaração tácita e comportamento concludente no negócio jurídico. Coimbra: Almedina, 1995.

ROXIN, Claus. Derecho Fenal: parte general. Fundamentos. La estrutura de la teoria del delito. Trad. espanhola de Diego-Manuel Luzón Peña, Miguel Díaz y García Conlledo e Javier de Vicente Remesal. Madrid: Civitas, 1997, t. I

SANTOS, Maurício Macêdo dos; SÊGA, Viviane Amaral. O consentimento do ofendido na teoria do delito. Disponível em: $<$ http://jus2 uol.com.br/doutrina/texto.asp?id=988>. Acesso em: 12 abr. 2008.

SERRA, Adriano Vaz. Causas justificativas do fato danoso. Boletim do Ministério da Justiça, Lisboa, n. 85, p. 104-109, abr. 1959.

STOCO, Rui. Tratado de Responsabilidade Civil. 7ed. Saao Paulo: Revista dos Tribunais, $200 \%$. 
TOLEDO, Francisco de Assis. Ilicitude penal e causas de sua exclusâa. Rio de Janeiro: Forense, 1984.

VARELA, Joăo de Matos Antunes. Das Obrigaçōes em Geral. ged. Coimbra: Almedina, 1998, vol. I.

VENOSA; Silvio de Salvo. Direito Civil Responsabilidade Civil bed. Săo Paulo: Atlas, 2006, vol. IV. 